\title{
DILUTION UNDER SECTION 43(c) OF THE LANHAM ACT
}

\author{
Miles J. AlexandeR* AND Michael K. Heilbronner**
}

\section{INTRODUCTION}

Because famous trademarks are widely recognized by consumers, they are likely victims of several types of actionable harm, including confusion, dilution, tarnishment, and other injuries based on damage to brand equity. In recognition of the value of famous trademarks and the need for comprehensive federal protection, in 1946, Congress passed the Federal Trademark Act, known as the Lanham Act. ${ }^{1}$ In its original form, the Lanham Act protected trademarks by prohibiting a broad array of conduct likely to cause confusion, deception, or mistake in the marketplace, but the act did not prohibit the "dilution" of a mark. $^{2}$ It thus excluded injuries caused by a blurring of the distinctiveness of a mark or tarnishment of the positive images associated with that mark.

The failure of federal law to fully protect the goodwill and the positive and exclusive associations developed by the trademark owner led twenty-seven states to enact dilution statutes. On January 16, 1996, the void in federal protection was filled when President Clinton signed into law the Federal Trademark Dilution Act of $1995,{ }^{3}$ which creates section 43(c) of the Lanham Act. Section 43(c) represents federal recognition of the dilution doctrine and the corresponding need to protect the goodwill embodied in the distinctiveness and commercial magnetism of well-known marks. ${ }^{4}$

Traditionally, the dilution doctrine targets two types of harm. First, the doctrine prevents use of a mark that causes the "blurring" or "whittling away" of the distinctive quality of a mark. This facet of the doctrine protects the ability of established marks to "evoke among prospective purchasers a positive

Copyright (O) 1996 by Law and Contemporary Problems

* Partner, Intellectual Property Section, Kilpatrick Stockton LLP.

** Associate, Intellectual Property Section, Kilpatrick Stockton LLP.

1. Act of July 5, 1946, 60 Stat. 427 (codified as amended at 15 U.S.C. $\S \S 1051-1127$ (1994)). Expanding the scope of federal trademark protection, the Lanham Act of 1946 abolished previous statutory language that conditioned trademark infringement on whether the goods had the "same descriptive properties" and moved to the broader test of likelihood of confusion, deception, or mistake. See Act of Feb. 20, 1905, ch. 592, 33 Stat 728 (superseded by The Lanham Trademark Act of 1946).

2. See 15 U.S.C. $\S \S 1114,1125$ (a) (1994).

3. Pub. L. No. 104-98, 109 Stat. 985 (codified at 15 U.S.C.A. $\$ 1125$ (c) (West Supp. 1996)).

4. It is an interesting coincidence that $\S 43$ (c) was adopted during the year in which we celebrated the 50th anniversary of the Lanham Act, as well as on the eve of the 50th anniversary of the adoption of the first state dilution statute in 1947. Act of May 2, 1947, ch. 307, 8 7(a), 1947 Mass. Acts 300, repealed by 1973 Mass. Acts 897 \& (current version at MASS. GEN. LAws ANN. ch. 110B, § 12 (West 1993)). 
response that is associated exclusively with the goods or services of the trademark owner."

The second harm targeted by the dilution doctrine is tarnishment. "The sine qua non of tarnishment is a finding that plaintiff's mark will suffer negative associations through defendant's use." ${ }^{\circ}$ Tarnishment cases often involve provocative or humorous uses of well-known marks, ${ }^{7}$ but "tarnishment is not limited to seamy conduct." ${ }^{\prime 8}$ Decisions finding dilution but not a likelihood of confusion are often based on the tarnishment prong, ${ }^{9}$ although several courts have found dilution from blurring in the absence of tarnishment or a likelihood of confusion. ${ }^{10}$

The new federal dilution statute has been hailed as a remedy for the "patchquilt system of protection"11 under the twenty-seven state dilution statutes. According to critics, the state statutes have been interpreted inconsistently and generally have not provided a common basis for nationwide injunctions. ${ }^{12}$

5. RESTATEMENT (THIRD) OF UNFAIR COMPETITION $\$ 25 \mathrm{cmt}$ c c (1995).

6. Hormel Foods Corp. v. Jim Henson Prods., 73 F.3d 497, 507 (2d Cir. 1996); Deere \& Co. v. MTD Prods., 41 F.3d 39, 43 (2d Cir. 1994) (explaining that tarnishment occurs when the junior use creates an undesirable, unwholesome, or unsavory mental association with the senior user's mark).

7. See, e.g., Hormel Foods, 73 F.3d at 501-02 (stating that use of "Spa'am" for name of porcine puppet character in children's movie not likely to dilute SPAM for lunch meat, despite defendant's intent to poke fun at the famous lunch meat); D.C. Comics, Inc. v. Unlimited Monkey Bus., 598 F. Supp. 110, 116 (N.D. Ga. 1984) (holding that use of "Super Stud" and "Wonder Wench" by singing telegram business dilutes SUPERMAN and WONDER WOMAN marks); see also cases cited infra note 138.

8. Hormel Foods, 73 F.3d at 507.

9. See, e.g., Deere, 41 F.3d at 45 (holding that use of Plaintiff's animated, scared version of "Deere" logo by competitor does not cause confusion but "risks possibility that consumers will come to attribute unfavorable characteristics to a mark and ultimately associate the mark with inferior goods"); American Express Co. v. Vibra Approved Labs., 10 U.S.P.Q.2d 2006, 2012-13 (S.D.N.Y. 1989) (enjoining sale of condom package consisting of replica of American Express card and featuring slogan NEVER LEAVE HOME WITHOUT IT on dilution theory only); Pillsbury Co. v. Milky Way Prods., 215 U.S.P.Q. 124 (N.D. Ga. 1981) (enjoining on dilution theory only the published portrayals of trade characters "Poppin' Fresh" and "Poppie Fresh" engaged in sexual intercourse and fellatio).

10. See, e.g., Intermatic Corp. v. Toeppen, No. 96 C 1982, 1996 WL 716892 (N.D. Ill. Nov. 2, 1996) (finding under $\$ 43(\mathrm{c})$ that INTERMATIC for sale and distribution of electronic products was diluted by INTERMATIC.COM used as Internet domain name); Panavision Int'l, L.P. v. Toeppen, CV 96-3284 DDP (JRX), 1996 WL 653726 (C.D. Cal. 1996) (finding under \$ 43(c) that PANAVISION for theatrical motion picture and television camera and photographic equipment was diluted by PANAVISION.COM used as Internet domain name); Ringling Bros.-Barnum \& Bailey Combined Shows, Inc. v. CelozziEttelson Chevrolet, Inc., 855 F.2d 480, 485 (7th Cir. 1988) (affirming injunction granted only under blurring prong); Community Fed. Sav. \& Loan Ass'n v. Orondorff, 678 F.2d 1034, 1037 (11th Cir. 1982) (reversing denial of injunction under blurring prong); Instrumentalist Co. v. Marine Corps League, 509 F. Supp. 323, 333 (N.D. Ill. 1981) (finding no likelihood of confusion, but granting relief under blurring prong), aff'd, 694 F.2d 145 (7th Cir. 1982); Wedgwood Homes, Inc. v. Lund, 659 P.2d 377, 382 (Or. 1983) (affirming injunction granted under blurring prong, and also affirming findings of no likelihood of confusion and no tarnishment).

11. H.R. REP. NO. 104-374, at 3 (1995), reprinted in 1995 U.S.C.C.A.N 1029, 1030.

12. Id. at 3-4. Some courts have granted national injunctions based on state dilution claims. See Stern's Miracle-Gro Prods. v. Shark Prods., 823 F. Supp. 1077, 1095-96 (S.D.N.Y. 1993); Eastman Kodak Co. v. Rakow, 739 F. Supp. 116, 120 n.3 (W.D.N.Y. 1989) ("Defendant's contention that the geographic scope of this injunction is limited to New York state is without merit."); Instrumentalist Co. v. Marine Corps League, 509 F. Supp. 323, 340 (N.D. Ill. 1981) ("It would be the height of absurdity to hold that Illinois had a legitimate interest in protecting vested rights . . . against dilution but that, having acquired 
Absent extraterritorial enforcement, owners of well-known marks arguably had to choose a favorable jurisdiction to assert dilution rights. ${ }^{13}$

Consistent with the legislative intent, section 43(c) appears to enhance significantly the arsenal available to owners of famous marks, but the language of the statute is subject to varying interpretations. The statute explicitly applies only to famous marks, ${ }^{14}$ a limitation that does not exist in specific language of most state statutes. ${ }^{15}$ Thus, although section $43(\mathrm{c})$ has been heralded for bringing uniformity and consistency to the law of dilution, an analysis of the language and history of section 43(c) reveals several potential pitfalls and subjects for interpretive dispute. It may not be a panacea for trademark owners.

This article examines section 43(c) in the context of the historical evolution of the dilution doctrine and the history of the statute and its meaning. Part II summarizes the historical development of the dilution doctrine in the United States, ultimately leading to the enactment of the federal dilution statute. Part III analyzes section $43(\mathrm{c})$, discussing a variety of theoretical issues and examining the potential practical effects of the statute.

jurisdiction over an offender, courts sitting in Illinois would be helpless to deal with dilutive acts once they crossed state lines."), aff'd, 694 F.2d 145 (7th Cir. 1982).

Additionally, other courts have confirmed their authority to grant extraterritorial injunctions. See Deere \& Co. v. MTD Prods., 41 F.3d 39, 46-47 (2d Cir. 1994) (affirming injunction covering New York State only, but suggesting that authority exists to grant broader relief); Polaroid Corp. v. Polarad, Inc., 319 F.2d 830 (7th Cir. 1963) (granting injunction in Illinois, Indiana, and Iowa). But see American Dairy Queen Corp. v. RTO, Inc., 16 U.S.P.Q.2d 1077, 1078 (N.D. Ill. 1990) (denying dilution relief, but doubting that "Illinois can impose its notions of good policy upon the other states"); Hyatt Corp. v. Hyatt Legal Services, 610 F. Supp. 381, 386 (N.D. Ill. 1985) (issuing nationwide injunction, but, under constitutional commerce clause analysis, staying portion effective outside Illinois).

13. A sensible alternative, however, is to file individual claims under each of the state statutes in one lawsuit. See Big Y Foods, Inc. v. Retail Marketing Network, Inc., No 94-30248-MAP, 1995 WL 88176, at *4 (D. Mass. Mar. 3, 1995) (finding dilution under Massachusetts, New York, Rhode Island, and Connecticut statutes); R.L. Winston Rod Co. v. Sage Mfg. Co., 838 F. Supp. 1396, 1399, 1402 (D. Mont. 1993) (finding no dilution, but acknowledging that Plaintiff brought dilution claims under laws of several states); Verified Complaint I 64, General Mills, Inc. v. Gag Foods, Inc. (D. Minn. Case No. 4-93-936) (alleging that ROADKILL HELPER diluted various marks owned by General Mills "in violation of the anti-dilution statutes and law of several states").

14. See 15 U.S.C. $\$ 1125(c)(1)$ (1994) ("The owner of a famous mark shall be entitled ....") (emphasis added).

15. But see CONN. GEN. STAT. § 35-11i(c) (West 1994); S.C. CODE ANN. § 39-15-1165(A) (Law. Coop. 1995); WASH. REV. CODE ANN. $\$ 19.77 .160$ (West Supp. 1996); MODEL ST. TRADEMARK BILL $\$ 13$ (U.S. Trademark Ass'n 1992) (as amended from former \$ 12), reprinted in INT'L TRADEMARK ASS'N, STATE TRADEMARK \& UNFAIR COMPETITION LAW 1-9 (1994); see also generally 3 J. THOMAS MCCARTHY, TRADEMARKS AND UNFAIR COMPETITION $\$ 24.17$, at 24-135 to -136 (3d ed. 1994) ("To save the dilution doctrine from abuse by plaintiffs whose marks are not famous and distinctive, a large neon sign should be placed adjacent to wherever the doctrine resides, reading: 'The Dilution Rule: Only Strong Marks Need Apply."'). 


\section{II}

\section{The Evolution of Section 43(c): A BRIEF History of the Dilution DOCTRINE LEADING TO THE FEDERAL STATUTE}

Historically, a trademark cause of action was based on tort doctrines of fraud or deceit, which prevented loss resulting from consumer deception, rather than trespass, which protected the property rights developed in a mark. ${ }^{16}$ Thus, traditionally, there could be no trademark infringement by a non-competitor because deception did not divert sales through "passing off" one person's goods as those of another. ${ }^{17}$ This rationale meant that, at early common law, a non-competitor could appropriate another's mark with impunity ${ }^{18}$

As improvements in travel and communication made it possible for marks to attain widespread fame, courts in various countries began to recognize that appropriation of a well-known mark could give a non-competitor an unfair and unearned advantage in the marketplace. In 1898, the Eastman Kodak Company successfully enjoined the use of the mark KODAK® on bicycles in the United Kingdom. ${ }^{19}$ Similarly, in 1924, a German court found that the owner of the famous mark ODOL for mouthwash was entitled to cancel a registration for ODOL for steel products, stating that the complainant had "the utmost interest in seeing that its mark is not diluted," and that, "it would lose in selling power if everyone used it as the designation of his goods." 20

These cases demonstrate that, in certain instances, courts of other nations may adapt to new commercial realities faster than courts in the United States. American courts have developed broader concepts of infringement to accommodate evolving commercial realities when necessary, ${ }^{21}$ but they generally have

16. See Beverly W. Pattishall, Dawning Acceptance of the Dilution Rationale for Trademark-Trade Identity Protection, 74 TRADEMARK REP. 289, 308-09 (1989). See also Jerre B. Swann \& Theodore H. Davis, Dilution, an Idea Whose Time Has Gone; Brand Equity as Protectable Property, the New/Old Paradigm, 1 J. INT. PROP. L. 219 (1994), reprinted in 84 TRADEMARK REP. 267 (1994) (arguing that trademarks should be treated as property because they are symbols with independent value and are entitled, under a trespass theory, to be protected like any other corporate asset).

17. Lever v. Goodwin, 36 Ch. D. 1, 2-3 (Ch. Div'l Ct. 1887) (English common law); Goodyear's India Rubber Glove Mfg. Co. v. Goodyear Rubber Co., 128 U.S. 598, 604 (1888) (granting relief only where defendant palms off its good for those of a different manufacturer and causes injury of plaintiff). See also Pattishall, supra note 16, at 308-09.

18. See Blanchard v. Hill, 26 Eng. Rep. 692, 2 Atkin 484 (1742) ("Every particular trader has some particular mark or stamp; but I do not know of any instance of granting an injunction . . . to restrain one trader from using the same mark with another, and I think it would be of mischievous consequence to do it.").

19. See Eastman Photographic Materials Co. v. John Griffiths Cycle Corp. 15 R.P.C. 105 (Ch. Div’l Ct. 1898).

20. Frank I. Schechter, The Rational Basis of Trademark Protection, 40 HARV. L. REV. 813, 831-32 (1927) (quoting the "Odol case" (citations omitted)).

21. See, e.g., Aunt Jemima Mills Co. v. Rigney \& Co., 247 F. 407 (2d Cir. 1917), cert. denied, 245 U.S. 672 (1918) (related goods doctrine) (enjoining use of AUNT JEMIMA by pancake syrup company even though the use was not competitive with Plaintiff's pancake flour). See also Polaroid Corp. v. Polarad Elecs. Corp., 287 F.2d 492, 495 (2d Cir. 1961), cert. denied, 368 U.S. 820 (1961) (setting forth standard for infringement cases involving noncompeting goods). In more recent years, the likelihood 
not recognized a cause of action for dilution under the common law. ${ }^{22}$ Occasionally, courts have expressed disapproval and granted a remedy when a party attempts to "reap where it has not sown" by misappropriating the goodwill in another's mark. No better articulation of this reaction exists than Judge Learned Hand's powerful prose in Yale Electric Corp. v. Robertson: ${ }^{23}$

[I]t has of recent years been recognized that a merchant may have a sufficient economic interest in the use of his mark outside the field of his own exploitation to justify interposition by a court. His mark is his authentic seal; by it he vouches for the goods which bear it; it carries his name for good or ill. If another uses it, he borrows the owner's reputation, whose quality no longer lies within his own control. This is an injury, even though the borrower does not tarnish it, or divert any sales by its use; for a reputation, like a face, is the symbol of its possessor and creator, and another can use it only as a mask. ${ }^{24}$

Commentators have also stressed the need for federal protection based on misappropriation of the brand equity developed in a mark. In his landmark 1927 article, The Rational Limits of Trademark Protection ${ }^{25}$ Frank I. Schechter introduced the dilution doctrine in the United States. Although never using the word "dilution" in this seminal work, Schechter concluded that protection of trade identity involves not only the question of deception of the public, but also protection against the vitiation of the "uniqueness and singularity" of that mark. ${ }^{26}$ By way of example, he noted that if courts permitted KODAK bath tubs and cakes, the mark would "inevitably be lost [among] the commonplace

of confusion concept has been expanded to "extend ... protection against use of [Plaintiff's] mark on any product or service which would reasonably be thought by the buying public to come from the same source or thought to be affiliated with, connected with, or sponsored by the trademark owner." Anheuser-Busch, Inc. v. Balducci Publications, 28 F.3d 769, 774 (8th Cir. 1994) (quoting 3 MCCARTHY, supra, note $15, \S 24.03$, at $24-13$ ). Thus, as presently conceived, a likelihood of confusion might include situations in which the consumer believes use of a mark is part of a line extension, a licensed use, or a private label version of the well-known brand. See, e.g., Cadbury Beverages, Inc. v. Cott Corp., 73 F.3d 474, 481 (2d Cir. 1996) (finding that a genuine issue of material fact exists about whether COTT used by private label soft drink manufacturer is likely to be confused with COTT used by branded soft drink manufacturer) ("Manufacturers of branded products often sell products under a private label.").

22. There are several exceptions to this general rule. See Ameritech v. American Info. Technologies Corp., 1 U.S.P.Q.2d 1861 (6th Cir. 1987) ("Dilution claims . . . are cognizable under Ohio's common law."); Hartford House, Ltd. v. Hallmark Cards, Inc., 647 F. Supp. 1533 (D. Colo. 1986), aff d, 846 F.2d 1268 (10th Cir.) (applying Colorado common law), cert. denied, 488 U.S. 908 (1988); Prince Mfg. v. Bard Int'l Assocs., 11 U.S.P.Q.2d 1419 (D.N.J. 1980) (applying New Jersey common law); Coors Co. v. A. Genderson \& Sons, Inc., 486 F. Supp. 131 (D. Colo. 1980) (applying Colorado common law); Kimberley Knitwear, Inc. v. Kimberley Stores, Inc., 331 F. Supp. 1339 (W.D. Mich. 1971) (applying Michigan common law). But see Aero-Motive Co. v. U.S. Aeromotive, Inc., 922 F. Supp. 29, 47 (W.D. Mich. 1996) ("[T]here is no common law cause of action for trademark dilution under Michigan law.") (citing Wynn Oil Co. v. American Way Servs. Corp., 736 F. Supp. 746, 756 (E.D. Mich. 1990), aff d in part and rev'd in part, 943 F.2d 595 (6th Cir. 1991)); Anheuser-Busch, Inc. v. Florist Ass'n of Greater Cleveland, 603 F. Supp. 35, 39 (N.D. Ohio 1984) (applying Ohio common law and explaining that dilution is a creature of statute and court will not create it).

23. 26 F.2d 972, 974 (2d Cir. 1928) (enjoining defendant's use of a mark similar to plaintiff's on related goods because YALE for flashlights and batteries likely to be confused with YALE for locks and keys).

24. Id. (emphasis supplied).

25. 40 HARV. L. REV. 813 (1927).

26. Id. at 831 . 
words of the language, despite the originality and ingenuity in their contrivance, and the vast expenditures in advertising."27

In 1932, Schechter and others unsuccessfully proposed the enactment of a federal trademark act known as the Perkins Bill. ${ }^{28}$ It contained dilution provisions protecting "coined or inventive or fanciful or arbitrary" registered marks against uses of the mark in a manner that might "injure the goodwill, reputation, business credit ... of the owner of the previously used mark."29 Congress took no action on the bill.

In 1946, in legislative history to the Lanham Act, Congress recognized the need for national and uniform protection of trademarks greater than that provided under existing federal trademark laws:

[T]rade is no longer local, but is national. Marks used in interstate commerce are properly the subject of federal regulation. It would seem as if national legislation along national lines securing to the owners of trademarks in interstate commerce definite rights should be enacted and should be enacted now. ${ }^{30}$

Despite congressional recognition of the need for additional protection, as well as scholarly and judicial sentiment recognizing the need for complete protection for dilution as well as confusion, deception, and false advertising, Congress failed to include a remedy for dilution in the Lanham Act. ${ }^{31}$

Congressional inaction, however, did not reduce judicial frustration with attempts to appropriate the "commercial magnetism" of well-known marks. In the same decade that the need for the Lanham Act was debated, and before it was adopted, Justice Frankfurter echoed Learned Hand's concern for propertylike value inherent in a developed mark, eloquently and succinctly describing the threat targeted by dilution statutes:

The protection of trade-marks is the law's recognition of the psychological function of symbols. [A] trade-mark is a merchandising short-cut which induces a purchaser to select what he wants, or what he has been led to believe he wants. The owner of a mark exploits this human propensity by making every effort to impregnate the atmosphere of the market with the drawing power of a congenial symbol. Whatever the means employed, the aim is the same-to convey through the mark, in the minds of potential customers, the desirability of the commodity upon which it appears. Once this is attained, the trademark owner has something of value. If another poaches upon the commercial magnetism of the symbol he has created, the owner can obtain legal redress. ${ }^{32}$

27. Id. at 830; see also Julius R. Lunsford, Jr., Trademark Basics, 59 TRADEMARK REP. 873, 879 (1969) ("If you allow Rolls Royce restaurants and Rolls Royce cafeterias, and Rolls Royce candy, in ten years you will not have the Rolls Royce marks any more."') (quoting Schechter's testimony at Hearings Before the House Committee on Patents, 72d Cong. 15 (1932)).

28. H.R. REP. No. 72-11592 (1932).

29. Walter J. Derenberg, The Problem of Trademark Dilution and the Antidilution Statutes, 44 CAL. L. REV. 439, 449 (1956) (citing Hearings Before the House Committee on Patents, 72d Cong. 15 (1932)).

30. S. REP. NO. 1333, 79-1333 (1946), reprinted in 1946 U.S.C.C.A.N. 1274, 1277.

31. See Community Fed. Sav. \& Loan Ass'n v. Orondorff, 678 F.2d 1034, 1036 n.7 (11th Cir. 1982) ("[T]he dilution doctrine is not embraced by the Lanham Trademark Act of 1946.").

32. Mishawaka Rubber \& Woolen Mfg. Co. v. S.S. Kresge Co., 316 U.S. 203, 205 (1942) (remanded for determination of damages for infringement of trade dress consisting of red circular plug embedded in the center of a heel of a shoe) (emphasis added). Modern courts also recognize that "commercial magnetism" represents a property right entitled to protection from "poachers." See, e.g., Augusta Nat'l, 
Other courts have since gone to great lengths to find a likelihood of confusion when dilution appeared to be the appropriate but unavailable remedy. ${ }^{33}$

The trend toward adoption of state dilution statutes was a response to judicial and scholarly concerns regarding a need for an express remedy for dilution. Massachusetts adopted the first dilution statute in $1947,{ }^{34}$ and twentysix other states have followed suit. ${ }^{35}$ Most state statutes are modeled after Section 12 of the Model State Trademark Bill, which was adopted in 1964 by the United States Trademark Association (the "USTA"). ${ }^{36}$

The uneven interpretation of state dilution statutes is well documented. ${ }^{37}$

Inc. v. Northwestern Mutual Life Ins. Co., 193 U.S.P.Q. 210 (S.D. Ga. 1976) ("Use of the name [Masters] will enable defendant to get a free ride upon the good will and reputation built up by the plaintiff, and to that extent the value of plaintiff's property right in its trade-mark [will be] diluted and rendered less valuable."); Adirondack Appliance Repair, Inc. v. Adirondack Appliance Parts, Inc., 538 N.Y.S.2d 118, 120 (N.Y. App. Div. 1989) ("[D]efendant's name change apparently allowed it to capitalize on ... the good will and reputation enjoyed by plaintiff.").

33. See, for example, Judge Elbert Tuttle's decision in Chemical Corp. of America v. AnheuserBusch, Inc., 306 F.2d 433 (5th Cir. 1962), cert. denied, 372 U.S. 965 (1963) (enjoining WHERE THERE'S LIFE ... THERE'S BUGS on basis of likelihood of confusion with plaintiff's WHERE THERE'S LIFE ... THERE'S BUD).

34. 1947 Mass. Acts 300, supra note 4.

35. The 26 other state dilution statutes are the following: ALA. CODE § 8-12-17 (1995); ARK. CODE ANN. \$ 4-71-113 (Michie Supp. 1995); CAL. BUS. \& PROF. CODE $\$ 14330$ (Deering 1995); CONN. GEN. STAT. \& 35-11i(c) (West Supp. 1996); DEL. CODE ANN. tit. 6, \& 3313 (Supp. 1995); Fla. STAT. \& 495.151 (West 1995); GA. CODE ANN. § 10-1-451 (Michie 1996); IDAHO CODE § 48-513 (Supp. 1996); ILL. REV. STAT. ch. 765, para. 1035/15 (Smith Hurd Supp. 1996); IOWA CODE $\$ 548.113$ (Supp. 1995); LA. REV. STAT. ANN. § 51:223.1 (West Supp. 1996); ME. REV. STAT. ANN. tit. 10, § 1530 (West Supp. 1995); MINN. STAT. § 325D.165 (Supp. 1995); MO. ANN. STAT. 417.061 (Vernon Supp. 1996); MONT. CoDE ANN. § 30-13-334 (1995); NEB. REV. STAT. ANN. § 87-122 (Michie 1995); N.H. REV. STAT. ANN. § 350A-12 (1996); N.M. STAT. ANN. § 57-3-10 (Michie 1996); N.Y. GEN. BUS. LAW § 368-d (McKinney 1996); OR. REv. STAT. § 647.107 (Supp. 1995); 54 PA. CONS. STAT. ANN. \$ 1124 (Supp. 1995); R.I. Gen. LawS § 6-2-12 (Supp. 1995); S.C. CODE ANN. § 39-15-1165(A) (Law Coop. 1996); TENN. CODE ANN. § 47-25512 (Supp. 1995); TEX. Bus. \& COM. CODE ANN. \$ 16.29 (West Supp. 1995); WASH. REv. COdE ANN. $\S 19.77 .160$ (West Supp. 1997).

36. As originally drafted, $\S 12$ of the Model Bill stated:

Likelihood of injury to business reputation or of dilution of the distinctive quality of a mark registered under this Act, or a mark valid at common law ... shall be a ground for injunctive relief notwithstanding the absence of competition between the parties or the absence of confusion as to the source of goods.

MODEL STATE TRADEMARK BILL $\$ 12$ (U.S. Trademark Ass'n 1964), reprinted in INT'L TRADEMARK ASS'N, ST. TRADEMARK \& UNFAIR COMPETITION LAW 1-9 (1994). In 1992, the dilution section of the Model Bill was amended and recodified as $\S 13$. See MODEL STATE TRADEMARK BILL $\S 13$ (U.S. Trademark Ass'n 1992) (as amended), reprinted in INT'L TRADEMARK ASS'N, STATE TRADEMARK \& UNFAIR COMPETITION LAW 1-9. Section 13 is substantially similar to the federal statute, and the Connecticut, South Carolina, and Washington statutes are modeled after $\S 13$ of the Model Bill.

Unlike the former $\S 12$ and most state statutes, amended $\S 13$ and the federal statute do not expressly protect against "likelihood of injury to business reputation." See infra part III.D. (discussing the possibility that the omission of the "injury to business reputation" language in the federal statute may be argued by some to preclude a claim under the tarnishment prong of the dilution doctrine despite contrary legislative intent).

37. See Jerome Gilson, A Federal Dilution Statute: Is It Time?, 83 TRADEMARK REP. 107, 110-11 (1993); Milton W. Handler, Are the State Antidilution Laws Compatible With the National Protection of Trademarks?, 75 TRADEMARK REP. 269 (1985); Pattishall, supra note 16, at 290-94; Beverly W. Pattishall, The Dilution Rationale for Trademark-Trade Identity Protection, Its Progress and Prospects, 71 Nw. U. L. REV. 618 (1977), reprinted in 67 TRADEMARK REP. 607 (1977); Comment, Dilution: Trademark Infringement or Will-O'-The-Wisp?, 77 HARV. L. REV. 520 (1964), reprinted in 54 
Prior to the late 1970 s, many courts were reluctant to give full effect to dilution statutes, often requiring "confusion," "intent," or "competition" as elements of a dilution cause of action, despite clear statutory language to the contrary. ${ }^{38}$ Commentators generally regard the 1977 New York Court of Appeals decision in Allied Maintenance Corp. v. Allied Mechanical Trades, Inc. ${ }^{39}$ as marking the beginning of a period of increasing judicial acceptance of the doctrine. ${ }^{40}$ Although finding no dilution, Allied Maintenance is significant because of the court's express holding that a claim under the New York statute is not barred by a lack of a likelihood of confusion or competition between the parties. ${ }^{41}$ The number of cases in which trademark owners successfully relied on state dilution statutes in the past twenty years, as opposed to the first thirty years of their existence, is illustrated by a state-by-state review of the dilution sections in the International Trademark Association's compendium of state trademark law. ${ }^{42}$

Ten years after Allied Maintenance, the Supreme Court, in San Francisco Arts \& Athletics, Inc. v. United States Olympic Committee, ${ }^{43}$ confirmed the constitutional validity of the dilution doctrine and the propriety of the concerns raised by Justice Frankfurter and others that "poaching" on the goodwill developed in a mark should not go unpunished. Facing a challenge to the validity of the Amateur Sports Act of $1978,{ }^{44}$ the Court held that it was lawful for Congress to grant the United States Olympic Committee exclusive use of the term "Olympic," whether or not another party's use of that term created a likelihood of confusion. Reaching this conclusion, the Court stated that Congress "could determine that unauthorized uses, even if not confusing, nevertheless may harm the [Olympic Committee] by lessening the distinctiveness and thus the commercial value of the marks." 45

The growing acceptance of the dilution doctrine coincided with the USTA Trademark Review Commission's 1987 proposal to add a section to the Lanham

TRADEMARK REP. 184 (1964).

38. See, e.g., Haviland \& Co. v. Johann Haviland China Corp., 269 F. Supp. 928 , 957 (S.D.N.Y. 1967) ("Plaintiff cannot claim right to relief under the New York State anti-dilution statute, since it has failed to show likelihood of confusion or unfair intent on the defendants' part.").

39. 369 N.E.2d 1162, 1166 (N.Y. 1977) (arguing that ALLIED for office cleaning services is not diluted by ALLIED for air conditioning and heating equipment installation services).

40. Pattishall, supra note 16, at 292 ("Allied Maintenance appears to have precipitated a change of course in the interpretation of the law of dilution.").

41. Allied Maintenance, 369 N.E.2d at 1165 (noting that dilution statutes prevent the "cancer-like growth" arising from the use of an identical mark on "dissimilar products or services which feeds upon the business reputation of an established distinctive trademark or name").

42. See generally InT'L TRADEMARK Ass'N, STATE TRADEMARK \& UNFaIR COMPETITION LAW (1994); see also Miles J. Alexander, Dilution-A Blessing or A Curse? What Is It? How Do You Prove It? How Does It Fit In With Traditional Trademark Law?, C962 A.L.I.-A.B.A. 1 (1994) (providing a state-by-state summary of dilution decisions).

43. 483 U.S. 522 (1987).

44. 36 U.S.C. $\$ \$ 371-96$ (1994) (imposing broad restrictions on use of the term "Olympic").

45. 483 U.S. at 539 (citing Schechter, supra note 20, at 825) (emphasis added). 
Act entitled "Protection of Famous Registered Marks From Dilution."46 Under this proposal, only registered, famous, and distinctive marks would have qualified for dilution protection. ${ }^{47}$ Although originally part of a broad series of proposals for much needed revisions of the Lanham Act, the proposal for section 43(c) was not included in the legislation ultimately adopted by Congress as the Trademark Law Revision Act of $1988 .{ }^{48}$ Members of the House expressed concerns that the bill would unduly limit First Amendment rights of advertisers. ${ }^{49}$

Support for a federal dilution statute remained vibrant, however, and the proposed section 43(c) continued to engender extensive debate among scholars and the bar after Congress dropped it from the 1987 legislation. $^{50}$ Advocates of a federal statute argued that dilution causes injury separate and distinct from a likelihood of confusion, and, therefore, marks should be protected separately against such harm. According to supporters, a uniform federal statute was necessary because the state statutes inadequately protected trademark owners. Proponents of the federal statute also argued that federal dilution legislation would be consistent with the terms of several international trade agreements and would facilitate negotiations for securing greater protection for U.S. marks abroad. ${ }^{51}$

Others continued to criticize the proposed statute on the grounds that dilution is philosophically unsound and that the federal statute would impinge free speech rights of third parties:

Dilution is variously and vaguely defined. . . Because proposed Section $43(\mathrm{c})$ grossly expands trademark rights, and expansion is only justified by a now out-dated and discredited version of natural rights, such an amendment is not wise. In fact, this

46. See United States Trademark Association, Trademark Review Commission, Report and Recommendations to USTA President and Board of Directors, 77 TRADEMARK REP. 375, 458-59 (1987) [hereinafter TRC Report]. The Trademark Review Commission was a special committee of nationally known members of the trademark bar and academia formed in 1985 by the United States Trademark Association (now the International Trademark Association) "to evaluate the effectiveness of the [U.S.] trademark system, including a study of all pertinent statutory laws, rules, regulations and case law, and to make recommendations for improvements." Id. at vii.

47. Additionally, as discussed infra in part II.D., the Trademark Review Commission proposed the enactment of separate sections for dilution by blurring $(\$ 43(\mathrm{c})$ ) and tarnishment (with proposed amendments to $\S 43(\mathrm{a})$ ). The proposed tarnishment and blurring provisions appear in $T R C$ Report, supra note 46 , at $433-34,458-59$.

48. Pub. L. No. 100-667, 102 Stat. 3935 (1988).

49. See H.R. REP. NO. 100-1028, 5-6 (1988).

50. See generally A.B.A. SEC. INT. PROP. L., 1994-1995 ANNUAL REPORT 191 (1995) (summarizing the section's past resolutions in favor of federal statute); Gilson, supra note 37; Kimbley L. Muller, Dilution Law: At a Crossroad? A Position of Advocacy in Support of Adoption of a Preemptive Federal Antidilution Statute, 83 TRADEMARK REP. 175 (1993); Kenneth L. Port, The "Unnatural" Expansion of Trademark Rights: Is a Federal Dilution Statute Necessary?, 85 TRADEMARK REP. 525 (1994).

51. See H.R. REP. No. 104-374, at 4 (1995), reprinted in 1995 U.S.C.C.A.N. 1029, 1030 (noting harmony between federal act and Agreement on the Trade-Related Aspects of Intellectual Property Rights, including Trade in Counterfeit Goods ("TRIPS") and the Paris Convention). With respect to "well-known" marks, Article 16 of TRIPS permits member countries to prohibit the use of a mark on goods or services that are not similar to those for which the well-known mark is registered if use of the junior mark would suggest a connection with the well-known mark and the owner of the well-known mark is likely to be damaged by use of the junior mark. See TRIPS, Dec. 15, 1993, Part II, \$ 2, art. 16. 
"unnatural" expansion of trademark rights would chill the development of trademark rights by others and shift the balance of protection of interests strongly in favor of the trademark holder at the expense of the consumer and uninvolved third parties. ${ }^{52}$

In late 1995, an amended version of the proposed federal dilution act was reintroduced, and both houses of Congress quietly passed the bill, which President Clinton signed on January 16, 1996. The enacted version of section 43(c) largely parallels the 1987 Trademark Review Commission's proposed statute. Not included, however, are the registration requirement in the 1987 proposal and the Commission's proposal for a separate section addressing tarnishment, which the Senate deleted from the legislation that became the Trademark Law Revision Act. ${ }^{53}$

III

\section{THE SCOPE AND EFFECT OF SECTION 43(C)}

Liability under the federal dilution statute is premised on terms generally similar to those in section 13 of the amended Model State Trademark Bill:

The owner of a famous mark shall be entitled, subject to the principles of equity and upon such terms as the court deems reasonable, to an injunction against another person's commercial use in commerce of a mark or trade name, if such use begins after the mark has become famous and causes dilution of the distinctive quality of the mark.

The term dilution means the lessening of the capacity of a famous mark to identify and distinguish goods or services, regardless of the presence or absence of-(1) competition between the owner of the famous mark and other parties, or (2) likelihood of confusion, mistake, or deception. ${ }^{54}$

As indicated by this language, a major distinction between the federal statute and most state dilution statutes is that a mark must be famous to qualify for protection. ${ }^{55}$ Thus, the legislative history states that " $[t]$ he purpose of [Section $43(\mathrm{c})$ ] is to protect famous trademarks from subsequent uses that blur the distinctiveness of the mark or tarnish or disparage it, even in the absence of a likelihood of confusion." As with the state statutes, liability is triggered when a junior user uses a mark in a manner that causes a mental connection between the junior user's mark and the senior user's mark. As a result of the connection, "the ability of the senior user's mark to serve as a unique identifier of the [senior user's] goods or services is weakened because the relevant public now also associates that designation with a new and different source."57

52. Port, supra note 50 , at 526-27.

53. See S. REP. No. 100-515, at 41 (1988), reprinted in 1988 U.S.C.C.A.N. 5577, 5603 (discussing deletion of proposed $\$ 43(\mathrm{a}))$.

54. 15 U.S.C.A. $\$ \$ 1125$ (c)(1), 1127 (West Supp. 1996) (emphasis added).

55. But see Connecticut, Washington, and South Carolina statutes cited supra note 15; see also MODEL ST. TRADEMARK BILL \& 13 (as amended), supra note 15.

56. H.R. REP. NO. 104-374, supra note 11, at 2, reprinted in 1995 U.S.C.C.A.N. 1029 (emphasis added) ("The purpose of H.R. 1295 is to protect famous trademarks from subsequent uses that blur the distinctiveness of the mark or tarnish or disparage it.").

57. 3 MCCARTHY, supra note $15, \S 24.13[1][b]$, at $24-108$. 
Instead of evoking an immediate response from purchasers, the senior mark is left to compete with similar marks. Over time, as other uses crowd the market for mental associations, the senior mark becomes ordinary. This process is based largely on the "blurring" prong of the dilution doctrine. The legislative history suggests that relief also may be available for "tarnishment" if a famous mark, appearing in a distasteful setting, causes a distortion of the positive association connected to a brand. However, the definition of dilution in the federal statute does not specifically mention such a negative association and does not contain the "injury to business reputation" language of most state dilution statutes. ${ }^{58}$

The federal statute should provide owners of famous marks a higher degree of stability and predictability for marketing and managing their marks. For example, under the federal statute, national injunctive relief is available when appropriate. The availability of this remedy was an important factor driving passage of the legislation because some courts have been reluctant to grant multi-state injunctive relief under state dilution statutes. ${ }^{59}$

Section 43 (c) also makes available the remedies set forth in sections $35(a)^{60}$ and $36^{61}$ of the Lanham Act, which authorize monetary relief subject to the court's discretion and the principles of equity. Relief under these sections is available if the junior user "willfully intended to trade on the owner's reputation or to cause dilution of the famous mark."62 Presently, dilution statutes in only three states provide for monetary recovery. ${ }^{63}$

The new federal law also includes several limitations that are arguably applicable to, but not expressed in, state dilution statutes. For example, section 43(c) exempts the following from liability: fair use of a famous mark in comparative commercial advertising or promotion to identify the competing goods or services of the owner of the famous mark; non-commercial use of a mark; and all forms of news reporting and news commentary. ${ }^{64}$

Additionally, section $43(\mathrm{c})(3)^{65}$ expressly creates a safe harbor for owners of federal registrations by exempting them from liability for dilution under state statutes or common law. This exemption encourages federal registration, and,

58. See infra part III.D. (discussing possibility that, because $\S 43$ (c) omits "injury to business reputation" language, the federal statute may not encompass the tarnishment prong of dilution, despite congressional intent).

59. See H.R. REP. No. 104-374, supra note 11, at 3, reprinted in 1995 U.S.C.C.A.N. 1029, 1030 ("IS]ome courts are reluctant to grant nationwide injunctions for violation of state law where half of the states have no dilution law."); see also supra note 12 (discussing cases in which courts granted national injunctive relief or acknowledged their right to do so under state dilution statutes).

60. 15 U.S.C. $\$ 1117$ (a) (1994).

61. Id. at $\S 1118$.

62. Lanham Act $\S 43(c)(2), 15$ U.S.C.A. $\S 1125$ (c)(2) (West Supp. 1996).

63. See Connecticut, South Carolina, and Washington statutes cited supra note 15.

64. See 15 U.S.C.A. $\$ 1125$ (c)(4) (West Supp. 1996). These exceptions are discussed in detail infra in part II.C.

65. 15 U.S.C.A. $\S 1125(c)(3)$ (West Supp. 1996). 
as with other parts of the federal statute, provides added security to federal registrants.

As this summary suggests, section 43 (c) is intended to increase judicial acceptance of the dilution doctrine. ${ }^{66}$ A detailed analysis of the federal statute, however, reveals a variety of issues open for interpretation and dispute. Many of these issues have been litigated under state dilution statutes. Because state cases provide significant precedent on these issues, they are likely to have ongoing value and relevance for courts interpreting and applying the federal statute. ${ }^{67}$ Likewise, although the 1987 proposed federal dilution act was not enacted, the Trademark Review Commission's commentary and the legislative history of the 1987 proposed statute provide important insight for interpreting the new federal statute. ${ }^{68}$

\section{A. The Fame and Distinctiveness Requirements of Section 43(c)}

Relief under section $43(\mathrm{c})$ is available only to owners of distinctive and famous marks. ${ }^{69}$ Only the three state statutes that track section 13 of the 1992 version of the Model State Trademark Bill have statutory language with a similar fame requirement. ${ }^{70}$ The absence of a fame requirement in the remainder of state statutes, however, has not prevented courts from analyzing whether a mark is sufficiently well-known and distinctive to qualify for

66. TRC Report, supra note 46 , at 455 ("We envision the courts adopting a more enthusiastic view of our proposed statute than they have of the state dilution laws."); see also id. at 457 ("[The statute] makes the availability of dilution protection nationally uniform and predictable.").

The early returns on these predictions are mixed. Some courts have taken an expansive view of the statute to protect owners of famous marks. See, e.g., Intermatic Corp. v. Toeppen, No. 96 C 1982, 1996 WL 716892, at *6 (N.D. Ill. Nov. 2, 1996) (finding dilution under $\S 43$ (c) based on "cyber-squatter['s] ... attempt to profit from the Internet by reserving and later reselling or licensing domain names back to the companies that spent millions of dollars developing the goodwill of a trademark."); Panavision Int'l, L.P. v. Toeppen, CV 96-3284 DDP (JRX), 1996 WL 653726 (C.D. Cal. 1996) (finding dilution under $\S 43(\mathrm{c})$ based on same defendant's appropriation of a different domain name).

In contrast, other courts have found no likelihood of dilution in cases that appear to be good examples of what Schechter considered to be the classic case of dilution, namely, appropriation of a distinctive mark on unrelated goods. See Ringling Bros.-Barnum \& Bailey Combined Shows, Inc. v. B.E. Windows Corp., 937 F. Supp. 204 (S.D.N.Y. 1996) (finding that GREATEST SHOW ON EARTH for circus and related entertainment services was not diluted by THE GREATEST BAR ON EARTH for bar and restaurant); American Express Co. v. CFK, Inc., 96-CV-72329, 1996 WL 622462 (E.D. Mich. 1996) (finding that DON'T LEAVE HOME WITHOUT ... family of marks for travel and financial services and related products was not diluted by DON'T LEAVE HOME WITHOUT ME POCKET ADDRESS BOOK for address book).

67. The federal statute does not preempt the state dilution statutes or the case law interpreting them. See H.R. REP. No. 104-374, supra note 11, at 4 ("It is important to note that H.R. 1295 would not pre-empt existing state dilution statutes. State laws could continue to be applied in cases involving locally famous or distinctive marks.").

68. See 3 MCCARTHY, supra note 15, \& 24.17[2], at 24-139 (noting that the views of the Commission and Congress are instructive for interpreting the fame requirement).

69. 15 U.S.C.A. \& 1125(c)(1) (West Supp. 1996).

70. See Connecticut, Washington, and South Carolina statutes cited supra note 15; MODEL STATE TRADEMARK BILL $\& 13$ (as amended), supra note 15 . 
protection..$^{71}$ In light of the varying results reached by many of these courts, and because the federal statute expressly requires fame and distinctiveness, the drafters of section $43(\mathrm{c})$ attempted to provide guidance with a series of nonexclusive factors for determining whether a mark qualifies for protection:

In determining whether a mark is distinctive and famous, a court may consider factors such as, but not limited to-

(A) the degree of inherent or acquired distinctiveness of the mark;

(B) the duration and extent of use of the mark in connection with the goods or services within which the mark is used;

(C) the duration and extent of advertising and publicity of the mark;

(D) the geographical extent of the trading area in which the mark is used;

(E) the channels of trade for the goods or services with which the mark is used;

(F) the degree of recognition of the mark in the trading areas and channels of trade used by the mark's owner and the person against whom the injunction is sought;

(G) the nature and extent of use of the same or similar marks by third parties; and

(H) whether the mark was registered under the Act of March 3,1881, or the Act of February 20,1905, or on the principal register. ${ }^{72}$

Some of these factors deal primarily with fame (whether a mark is sufficiently well-known to warrant federal protection), and others focus primarily on distinctiveness (whether a mark is capable of being diluted). All of the factors represent an attempt to add stability and consistency to dilution case law by providing objective criteria for determining whether marks qualify for federal protection. ${ }^{73}$ According to the Trademark Review Commission, the fame and distinctiveness requirements limit the scope of the statute to the marks that most need protection:

Famous marks are most likely to be harmed by reduced distinctiveness. They are enormously valuable but fragile assets, susceptible to irreversible injury from promiscuous use. Although they are occasionally protected on likelihood of confusion grounds, we are convinced they deserve dilution protection which is both effective and predictable. $^{74}$

The Commission further suggested that the federal statute should be "highly selective" and applied to a limited class of marks. ${ }^{75}$ As a result, the federal statute appears to provide narrower protection than the state dilution statutes.

71. Compare Mead Data Central, Inc. v. Toyota Motor Sales U.S.A., Inc., 875 F.2d 1026, 1031 (2d Cir. 1989) (holding that LEXIS for information retrieval services not diluted by LEXUS for automobiles, and noting that "if a mark circulates only in a limited market, it is unlikely to be associated generally with the mark for a dissimilar product circulating elsewhere"), with Dreyfus Fund, Inc. v. Royal Bank of Can., 525 F. Supp. 1108, 1125 (S.D.N.Y. 1981) ("The statute should not be read to deprive marks from protection against dilution in limited areas of use, since otherwise it would afford protection only to the most notorious of all marks."); Wedgwood Homes, Inc. v. Lund, 659 P.2d 377, 381 (Or. 1983) ("We see no reason why marks of national renown should enjoy protection while local marks should not. A small local firm may expand efforts and money proportionately as great as those of a large firm in order to establish its mark's distinctive quality.").

72. See 15 U.S.C.A. $\$ 1125($ c)(1)(A)-(H) (West Supp. 1996) (emphasis added).

73. See generally H.R. REP. No. 104-374, supra note 11, at 3 ("[The federal statute] will bring uniformity and consistency.").

74. TRC Report, supra note 46 , at 455. Act.").

75. Id.; see also id. at 456 ("We propose adding a narrowly drawn dilution section to the Lanham 
1. The Difficulty of Evaluating "Fame" and "Distinctiveness." Despite the recitation of these guiding factors, as well as the legislative intent that they be applied narrowly, the fame and distinctiveness factors are open-ended and involve many variables. Because fame and distinctiveness are threshold issues under the statute, and because both are amorphous concepts, litigants are likely to dispute vigorously whether plaintiff's mark satisfies these requirements.

For example, the fame requirement implies a quantitative inquiry (how famous the mark is), but the statute neither defines "famous" nor identifies the degree of notoriety sufficient to make a mark "famous." of cases involving undeniably famous marks such as COKE $®$, XEROX $®$, ROLLS ROYCE $®$, KODAK $®$, MICROSOFT $®$, etc., there will be little doubt about whether a mark is famous. In most situations, however, the fame inquiry will be fact-sensitive, and courts are likely to reach different results under similar facts. As with many issues in trademark litigation, whether a mark is famous will depend largely on the quantity and quality of evidence presented to the fact finder. A well-conducted survey and other evidence of "actual fame" 77 or, alternatively, evidence that a mark is not famous may be highly probative. $^{78}$

Whether a mark is sufficiently distinctive to be capable of being diluted is a similarly open-ended question, and a mark's position on the "spectrum" of distinctiveness will not be dispositive. ${ }^{79}$ Even well-known, inherently distinctive

76. Noting the imprecise nature of the term "famous," one commentator identifies eight synonymous and equally vague terms used in international treaties and trademark laws: "well-known; notorious; exceptionally well-known; highly renowned; highly reputed; marks with a (high) reputation; and marques de haut renommee." David H. Tatham, What is a Famous Brand? 14 (1995) (paper delivered in connection with speech at MARQUES 1995 Annual Conference). Tatham offers a definition for the term "famous" in the context of international fame:

A famous mark is a mark which is extremely widely known in the country concerned to at least $80 \%$ of the potential purchasers of the goods or services for which it is known, and to at least $90 \%$ of the relevant trade circles. Furthermore a famous mark must be a registered mark at least in its owner's home territory, and have a value, calculated by an internationally acceptable method, of at least $\$ 4000$ [sic] million.

Id. at 22 (emphasis original).

77. By "actual fame," the authors mean evidence showing in fact that plaintiff's mark is not only promoted, advertised, or otherwise held out to the relevant class of consumers, but also received and recalled by the relevant class of consumers. Thus, while evidence of significant advertising expenditure may provide indirect evidence of fame, testimony, surveys, or unsolicited media coverage showing the effectiveness of the advertisements would constitute evidence of "actual fame." See, e.g., Harlequin Enters., Ltd. v. Gulf \& Western Corp., 644 F.2d 946, 950 (2d Cir. 1981) (noting that unsolicited media coverage contributed to strong secondary meaning of "Harlequin Presents" book cover trade dress).

78. If a mark is promoted and advertised extensively, but defendant demonstrates that consumers have not retained an impression of the mark, the fame requirement may not be satisfied. See, e.g., Mead Data Cent., Inc. v. Toyota Motor Sales, U.S.A., Inc., 875 F.2d 1026, 1028 (2d Cir. 1989) (stating that surveys showed that LEXIS for computerized research service was famous among attorneys but virtually unknown among general public).

79. Trademark law uses a spectrum of distinctiveness. Marks generally are classified as coined, arbitrary, suggestive, descriptive, and generic. Coined, arbitrary, and suggestive marks are considered "inherently distinctive," while descriptive and generic marks are not. See generally RESTATEMENT, supra note $5, \S 13$. It is possible for a descriptive mark to "acquire" distinctiveness and great strength 
marks may be incapable of being diluted if there is extensive third-party use. Under this theory, Domino's Pizza, Inc., successfully argued that its mark DOMINO'S for pizza delivery services did not dilute Amstar's arbitrary and famous mark DOMINO for sugar. ${ }^{80}$

\section{The Flexibility of the Individual Fame and Distinctiveness Fac-} tors. Because of the evidentiary sensitivity of the fame and distinctiveness determinations, litigants are likely to dispute the relevance of each of the individual factors enumerated in section 43(c). For example, under fame factor (A) ${ }^{81}$ the degree of inherent or acquired distinctiveness is relevant to whether a mark is famous. Although a famous mark with sufficient acquired distinctiveness qualifies for protection ${ }^{82}$ the statute provides no guidance for determining the degree of acquired distinctiveness necessary.

Facing a similar issue under state dilution statutes, courts historically have disagreed about the level of distinctiveness necessary for a dilution claim. Many courts apply the distinctiveness requirement narrowly, ${ }^{83}$ while others grant relief to arguably weak marks. ${ }^{84}$ Professor McCarthy notes the difficulty of making "value judgments about the 'strength' of a mark sufficient to be

based on proof of a high degree of "secondary meaning." Secondary meaning refers to public recognition that the name does not simply refer to the nature of the user's products in a descriptive sense, but also serves to identify the source of origin of the goods or services. Id. $\$ 13 \mathrm{cmt}$. e.

80. Amstar Corp. v. Domino's Pizza, Inc., 615 F.2d 252, 265 (11th Cir.), cert. denied, 449 U.S. 899 (1980).

81. 15 U.S.C.A. § 43(c)(1)(A) (West Supp. 1996).

82. See H.R. REP. No. 104-374, supra note 11, at 7 ("[A] mark may be deemed 'famous' even if not inherently distinctive.").

83. See, e.g., Fruit of the Loom, Inc. v. Girouard, 994 F.2d 1359, 1362 (9th Cir. 1993) (holding that FRUIT OF THE LOOM for undergarments not diluted by FRUIT FLOPS and FRUIT CUPS for thongs and bustiers: "[FRUIT is a] strong mark in the apparel industry . . but . . . not strong enough to deserve protection under the California [dilution] law"); Mead Data Cent., Inc., 875 F.2d at 1031 ("[The] mental association may be created where the plaintiff's mark is very famous and therefore has a distinctive quality for a significant percentage of defendant's market."); Sally Gee, Inc. v. Myra Hogan, Inc., 699 F.2d 621, 625 (2d Cir. 1983) (stating that New York statute protects only "extremely strong marks" and may not even protect some arbitrary or fanciful marks); Glen Raven Mills, Inc. v. Ramada Int'l, Inc., 852 F. Supp. 1544, 1554-55 (M.D. Fla. 1994) (stating that mark must be "highly distinctive").

84. See, e.g., Regal Indus. v. Genal Strap, Inc., 33 U.S.P.Q.2d 1289, 1295 (E.D. Pa. 1994) (SPORTSTRAP for sport watchbands diluted by SPORTSTRAP also for watchbands), aff $d$ in part and appeal dismissed in part, 68 F.3d 457 (3d Cir. 1995); Midwest Research Inst. v. S \& B Promotions, Inc., 677 F. Supp. 1007 (W.D. Mo. 1988) (MIDWEST RESEARCH INSTITUTE for scientific research diluted by MIDWEST RESEARCH for subliminal self-help tapes); Chassis Master Corp. v. Borrego, 225 U.S.P.Q. 1240 (S.D. Fla. 1985) (CHASSIS MASTER diluted by MISTER CHASSIS both for auto repair shops); Shop-Rite Durable Supermarket, Inc. v. Mott's Shop Rite, Inc., 377 A.2d 312 (Conn. 1977) (SHOP-RITE for grocery stores diluted by SHOP-RITE on storefronts of super markets); Blanding Automotive Repair Ctr., Inc. v. Blanding Automotive, Inc., 568 So.2d 490 (Fla. Dist. Ct. App. 1990) (BLANDING AUTOMOTIVE for auto repair services diluted by same mark for similar services); Adirondack Appliance Repair, Inc. v. Adirondack Appliance Parts, Inc., 538 N.Y.S.2d 118 (App. Div. 1989) (ADIRONDACK APPLIANCE REPAIR diluted by ADIRONDACK APPLIANCE PARTS); Chase Medical Group v. Palmetto Clinic Ctr., 549 So.2d 1111 (Fla. Dist. Ct. App. 1989) (PALMETTO MEDICAL CENTER for medical services diluted by PALMETTO CLINIC CENTER for medical services). 
diluted" 85 but suggests that, "[t]o be capable of being diluted, a mark must have a degree of distinctiveness and 'strength' beyond that needed to serve as a trademark." ${ }^{\prime 86}$ Although there are a variety of methods of establishing the requisite level of strength, evidence showing actual recognition or nonrecognition of the mark may be significant. ${ }^{87}$

Factors (B) and $(C)^{88}$ address the duration and extent of use and advertising of the mark and, like factor (A), are susceptible to evidentiary disputes. ${ }^{89}$ The fact that a mark has or has not been used or advertised for a long time may not be dispositive. For example, a mark that has been in use for decades may not be sufficiently recognizable to be capable of generating the mental association necessary for dilution to occur. ${ }^{90}$ In contrast, prolific and creative marketing campaigns may render a mark famous "overnight." 11 Thus, whether fame exists under the length of use and advertising factors will depend on both quantitative and qualitative evidence. Prolific but unsuccessful use or advertising may not demonstrate fame, ${ }^{92}$ while marketing research indicating that positive and retained consumer response to a limited advertising campaign may be strong evidence of fame. ${ }^{93}$

85. 3 MCCARTHY, supra note $15, \S 24.17[4]$, at $24-141$.

86. Id. § 24.17[2], at 24-139; see also Wedgwood Homes, Inc. v. Lund, 659 P.2d 377, 379 (Or. 1983) ("We realize that the distinctiveness adequate to identify the origin of a product may be different from the distinctive quality deserving protection from dilution.").

87. See Moore Push-Pin Co. v. Moore Business Forms, 678 F. Supp. 113, 118 (E.D. Pa. 1987) (holding that MOORE for fastening and hanging devices not diluted by MOORE for adhesive "post-it" note pads: "No survey or other evidence pointed to an association between 'Moore' and Moore PushPin in the mind of a large segment of the public or the populace where Moore Push-Pin does business."); Wedgwood Homes, 659 P.2d at 381 ("At trial plaintiff demonstrated, by means of survey evidence, a high association between the words 'Wedgwood' and 'Homes' in the minds of consumers."); Ernst Hardware Co. v. Ernst Home Ctr., Inc., 895 P.2d 1363, 1366-67 (Or. Ct. App.) (weighing credibility of expert, survey-based testimony on distinctiveness and finding ERNST'S for industrialgrade machinery and hardware products not diluted by ERNST'S for noncompeting traditional hardware store), rev. denied, 900 P.2d 509 (Or. 1995).

88. 15 U.S.C.A. $\$ 1125$ (c)(1)(B), (C) (West Supp. 1996).

89. The legislative history for factor (B) is completely open-ended: “[G]enerally a famous mark will have been in use for some time." H.R. REP. No. 104-374, supra note 11, at 7 (emphasis supplied).

90. Genovese Drug Stores, Inc. v. TGC Stores, Inc., 939 F. Supp. 340, 347 (D.N.J. 1996) (stating that despite nine years of use and millions of dollars of advertising expenditure, "Plaintiff has not shown ... that the slogan by itself has any commercial recognition" and holding that WE'LL TAKE GOOD CARE OF YOU for drug stores not diluted under federal statute by TAKE GOOD CARE for retail sales of durable, home health care equipment); Tower Publications, Inc. v. MTS, Inc., 21 U.S.P.Q.2d 1303,1306 (N.D. Ill. 1991) (explaining that despite 18 years of continuous use, plaintiff's mark was not sufficiently well-known to qualify for dilution protection and holding TOWER RECORDS for publications of state agency opinions not diluted by TOWER RECORDS for magazine distributed by retail music and entertainment store).

91. See, e.g., Selchow \& Righter Co. v. Decipher, Inc., 598 F. Supp. 1489, 1496 (E.D. Va. 1984) (discussing "unprecedented success" of TRIVIAL PURSUIT trivia game, with sales of over 14 million units in first year and nine months on the market: "The TRIVIAL PURSUIT phenomenon spans the entire United States.").

92. FM 103.1, Inc. v. Universal Broad. of N.Y., Inc., 929 F. Supp. 187, 196 (D.N.J. 1996) (stating that a party claiming notoriety of a mark must "explain[] how its efforts were effective in causing the relevant group of consumers to associate the mark with [the party]").

93. See Selchow \& Righter Co., 598 F. Supp. at 1496 (explaining that despite a "small" amount of advertising, fame of TRIVIAL PURSUIT game demonstrated by, inter alia, newspaper and magazine 
Fame factor (D) involves the geographic extent of Plaintiff's trade. According to the legislative history, "the geographic fame of a mark must extend throughout a substantial portion of the [United States]." ${ }^{\text {" Th }}$ Trademark Review Commission acknowledged the ambiguity of the term "substantial":

The exact parameters of how much is substantial should be left to a case-by-case analysis, depending on the type of goods or services and their channels of distribution..$^{9}$

We did not employ the terms "majority" or "substantial majority" because we believed they would impair flexibility. We also did not employ the term "appreciable number" from the many decisions holding that likelihood of confusion must be established with respect to an appreciable number of ordinary prudent purchasers. Under these decisions the threshold is quite low. We believe that a higher standard should be employed to gauge the fame of a trademark eligible for this extraordinary remedy. ${ }^{96}$

Apparently, then, "substantial" may mean less than a majority, but the minimum quantum for demonstrating fame is higher than the "appreciable number" standard in the infringement context. Because of the ambiguity of the term "substantial," the types of disputes that have occurred in the past about the sufficiency of plaintiff's geographic use are likely to recur under the federal statute. ${ }^{97}$

The potential problem of regional fame has not troubled two courts that have considered whether regionally-famous marks were diluted under the federal statute. In Wawa, Inc. v. Haaf, ${ }^{98}$ the court found that plaintiff's mark WAWA for convenience stores was diluted under section 43(c) by defendant's mark HAHA, also used for convenience stores. WAWA operated 500 convenience stores in the states of Pennsylvania, New Jersey, Maryland, Delaware, and Connecticut. ${ }^{99}$ Without considering whether fame in such a limited geographic area precluded application of section 43(c), the court determined that plaintiff satisfied the fame requirement because plaintiff had used the WAWA mark and advertised it extensively for almost ninety years. ${ }^{100}$

Similarly, in Gazette Newspapers, Inc. v. New Paper, Inc. ${ }^{101}$ the court found that plaintiff's GAZETTE family of marks, which was used in connection

articles and TRIVIA PURSUIT tournaments).

94. H.R. REP. No. 104-374, supra note 11, at 7; see also TRC Report, supra note 46, at 456.

95. TRC Report, supra note 46 , at 460.

96. Id. at 461.

97. See, e.g., Ameritech, Inc. v. American Info. Technologies Corp., 811 F.2d 960, 965 (6th Cir. 1987) ("Plaintiff's trademark need not be nationally famous[; . . . a mark that is strong in a particular geographical or product area also deserves protection."); Wedgwood Homes, Inc. v. Lund, 659 P.2d 377, 381 (Or. 1983).

98. 40 U.S.P.Q.2d 1629 (BNA) (E.D. Pa. 1996).

99. Id.

100. Id. (the mark "has become synonymous with the operation of a 24 hour convenience store").

Plaintiff also owned incontestible federal registrations for the WAWA mark. Id.

101. 937 F. Supp. 688 (D. Md. 1996). 
with weekly newspapers sold in various Maryland suburbs, ${ }^{102}$ was diluted under sectior 43 (c) by THE FREDERICK GAZETTE, also for a community newspaper. ${ }^{103}$ "Thus, the most that one could say about plaintiff's family of marks is that they were famous in two Maryland counties. Paying lip service to the fame requirements, ${ }^{104}$ the court found dilution under the federal statute without any consideration of the fact that plaintiff's mark was arguably famous only in a portion of one state.

A corollary issue to geographic fame, assuming a mark is famous only in a portion of the United States, is whether a national injunction is available. Dilution is actionable under section 43 (c) only when a party uses a mark after the mark has become famous. ${ }^{105}$ Because an injunction covering areas in which a mark is not famous would effectively be granting relief before the mark became famous in those areas, the language of the statute may not support an anticipatory national injunction in favor of a regionally famous mark.

On the other hand, the statute does not state expressly that national relief is unavailable to a regionally famous mark. If the fame requirement is interpreted as the only condition precedent to relief, a mark that is famous in any substantial portion of the United States may be entitled to all available relief, subject only to the principles of equity and the court's discretion. ${ }^{106}$ For example, it may be equitable to grant a national injunction if a defendant intentionally adopts a mark knowing it is famous in a substantial part of the United States, and scheduled to be rolled out in other areas, in order to trade upon the commercial magnetism of the mark. On the other hand, if the owner of a regionally famous mark cannot establish a likelihood of dilution in areas in which its mark is not famous, national injunctive relief would be inappropriate. $^{107}$

102. Examples include the Gaithersburg Gazette, Montgomery Gazette, Rockville Gazette, etc. Id. at $690 \mathrm{n} .1$. Plaintiff also referred to itself or its publications using the GAZETTE mark. Id. at 690-91 (references include "Gazette Newspapers" and "Gazette").

103. Defendant's publication circulated mainly in Frederick County, Maryland. Id. at 691 . Although plaintiff's newspapers circulated in an adjacent county, the court found that plaintiff's publications are circulated and known throughout Frederick County. Id.

104. The court cited the fame factors. See id. at 697 n.6.

105. 15 U.S.C.A. \& 1125 (c)(1) (West Supp. 1996).

106. Id. Even before the enactment of the "constructive use" provisions of the Trademark Law Revision Act of 1988, federal registration generally provided the registrant with anticipatory national priority against junior users of the mark, but only after the registrant expanded its use or reputation into the junior user's area. See, e.g., Dawn Donut Co. v. Hart's Food Stores, Inc., 267 F.2d 358 (2d Cir. 1959) (denying injunctive relief because no likelihood of confusion when federal registrant's mark was not known in the junior user's trade area). By analogy, the owner of a famous mark might make a similar argument with regard to its right to expand. A mitigating factor against such a claim, however, is the fact that registration can be identified by a search, whereas fame and distinctiveness cannot readily be ascertained absent a system for compiling and tracking famous and distinctive marks.

107. In this regard, geographic rights principles from the infringement context may be instructive for determining whether a likelihood of dilution exists in areas remote from the senior user's zone of reputation. See, e.g., Dawn Donut Co., 267 F.2d at 364-65. 
Factors $(E)^{108}$ and $(F)^{109}$ involve the degree of recognition of plaintiff's mark in the respective channels of trade. These factors raise the following questions: Will fame within particular channels of trade or a particular market suffice? Will it be a limiting factor? The Mead Data Central case demonstrates that the answer to both questions might be "yes."

In Mead Data Central, the plaintiff established that its LEXIS mark was famous only within the limited market of attorneys and accountants. ${ }^{110}$ Because defendant's LEXUS mark would be used in connection with an automobile offered and marketed to the general public, the court determined that plaintiff's mark lacked sufficient notoriety among the general public to generate the mental association necessary for dilution to occur. Surveys showed that only one percent of the public recognized plaintiff's LEXIS mark, and "such distinctiveness as LEXIS possesses is limited to the narrow market of attorneys and accountants. Moreover, the product which LEXIS represents is widely disparate from the product represented by LEXUS. For the general public, LEXIS has no distinctive quality that LEXUS will dilute."111

The narrow scope of the plaintiff's channels of trade and the breadth of the defendant's were significant factors limiting the likelihood of dilution. ${ }^{112} \mathrm{Had}$ the plaintiff used the LEXIS mark in different channels of trade, or, perhaps if the evidence showed that the defendant's automobiles were marketed to a segment of the public disproportionately represented by those familiar with the LEXIS mark, the court might have reached a different conclusion. ${ }^{113}$

Although the court found that the "recognized sophistication" of attorneys and accountants would prevent "any significant amount of blurring," 114 implicit in the decision is the possibility that the "consuming public" of attorneys and accountants could have been large enough to create a likelihood of dilution. ${ }^{115}$ Likewise, if the LEXUS mark was principally used in channels of trade

108. 15 U.S.C.A. $\S 1125$ (c)(1)(E) (West Supp. 1996).

109. Id. $\S 1125(\mathrm{c})(1)(\mathrm{F})$.

110. Mead Data Cent. v. Toyota Motor Sales, U.S.A., 875 F.2d 1026, 1031 (2d Cir. 1989).

111. Id.

112. Id.; see also Astra Pharm. Prods. v. Beckman Instruments, Inc., 718 F.2d 1201, 1210 (1st Cir. 1983) (stating that, because there is sufficient dissimilarity in markets to prevent dilution, ASTRA for local anesthetic is not diluted by ASTRA for blood analyzer machine); PPG Indus. v. Clinical Data, Inc., 620 F. Supp. 604, 609 (D. Mass. 1985) (holding that PPG for paint not diluted by PPG for medical diagnostic supplies because plaintiff's products are unrelated to treatment of patients while [defendant] provides highly technical, specialized service used by pediatricians).

113. The court apparently disregarded circumstantial evidence to this effect, however, stating "[the] marketing pitch [for LEXUS automobiles] will be directed to well-educated professional consumers with annual incomes in excess of $\$ 50,000$." Mead Data Cent., Inc., 875 F.2d at 1028 . Perhaps plaintiff could have brought the point to the court's attention through direct evidence, such as a survey or other data, showing that the potential market for LEXUS automobiles included a disproportionate number of lawyers and accountants. Neither the Second Circuit or district court opinions suggest that plaintiff offered such evidence. See id.; see also Mead Data Cent., Inc. v. Toyota Motor Sales U.S.A., Inc., 702 F. Supp. 1031 (S.D.N.Y. 1988).

114. Mead Data Cent., Inc., 875 F.2d at 1031-32.

115. See generally RESTATEMENT, supra note $5, \S 25 \mathrm{cmts}$. e-f, reporter's note (1995) (discussing possibility of dilution of marks with distinctiveness in certain trade or geographical areas). 
frequented by attorneys and accountants, there may have been a likelihood of dilution among a sufficient amount of the consuming public to warrant relief.

The same principle may apply in other discrete markets and channels of trade to demonstrate or refute a likelihood of dilution. ${ }^{116}$ For example, children may be less sophisticated than attorneys and accountants and, therefore, more prone to diluting mental associations. As a result, dilution may be more likely for famous and distinctive marks used in connection with goods and services marketed primarily to children. ${ }^{117}$ Similarly, the class of nonEnglish speaking consumers may itself be a relevant market under the statute. Foreign language marks, or other marks predominantly used in markets and channels of trade occupied by non-English-speaking customers, may be famous and distinctive in particular markets but not in others. ${ }^{118}$ In these types of cases involving particular markets and channels of trade, as in Mead Data Central, the type of evidence will be as important as the amount of evidence if either party claims that market-specific factors increase or decrease the likelihood of dilution.

Again, principles of equity may limit the scope of injunctive relief available to a plaintiff that can establish dilution only in a particular market or channels of trade. ${ }^{119}$ Comprehensive injunctive relief may be inappropriate in markets or channels of trade in which the plaintiff's mark is not famous and distinctive, or in which there is no likelihood of dilution. ${ }^{120}$

Factor $(G)^{121}$ is the nature and extent of use of the same or similar marks by third parties. Even famous marks that are widely used by third parties may be incapable of being diluted under section 43(c): "Many marks claimed to

116. See Hester Indus. v. Tyson Foods, Inc., 16 U.S.P.Q.2d 1275 (N.D.N.Y. 1990) (finding WINGDINGS for chicken wings sufficiently well known in institutional food industry to raise a genuine issue of fact about the likelihood of dilution).

117. See Original Appalachian Artworks, Inc. v. Topps Chewing Gum, Inc., 642 F. Supp. 1031, 1037 38 (N.D. Ga. 1986) (finding that because children ages seven through twelve occupy a "substantial part of the market for both the plaintiff's and defendant's goods," and a survey showed that children in this age group "associated the two marks to a greater extent than adults," CABBAGE PATCH KIDS for dolls was diluted by GARBAGE PAIL KIDS for trading cards).

118. For example, the mark GOYA for foods is probably famous among Hispanic Americans, but may not be famous among other consumers. Courts have found that a likelihood of confusion and dilution may be enhanced when Spanish-speaking customers are part of the relevant market. See Chassis Master Corp. v. Borrego, 225 U.S.P.Q. 1240, 1242 (S.D. Fla. 1985) (finding dilution and a likelihood of confusion) ("Spanish[-]speaking customers in Miami regularly refer to CHASSIS MASTER as 'Master Chassis.' Thus, by merely changing one letter of a word Borrego was able to capitalize on the Chassis Master name and reputation."); Arthur Matney Co. v. Halcyon Essences Ltd., 207 U.S.P.Q. 77, 79 (E.D.N.Y. 1979) (finding a likelihood of confusion and stating that SELENE is confusingly similar to SERENA "especially ... to the Spanish-speaking customers to whom all parties agree this product was addressed").

119. RESTATEMENT, supra note $5, \S 25 \mathrm{cmt}$. e ("A mark that is highly distinctive only to a select class or group of purchasers may be protected from diluting uses directed at that particular class or group. ... Uses of the mark in broader markets, although they may produce an incidental diluting effect in the protected market, are not normally actionable.").

120. See, e.g., Dreyfus Fund, Inc. v. Royal Bank of Can., 525 F. Supp. 1108, 1124 (S.D.N.Y. 1981) (discussing possibility that injunctive relief is only appropriate against advertisements in a related field).

121. 15 U.S.C.A. \& $1125(\mathrm{c})(1)(\mathrm{G})$ (West Supp. 1996). 
have been 'diluted' have been held to be already so 'diluted,' weak and commonplace that there is no distinctive quality left to dilute by others." 122 Thus, the mark McDONALD'S, a surname with strong secondary meaning, has acquired and retained distinctiveness in the restaurant and hospitality industries, ${ }^{123}$ but extensive third-party use of the surname (as opposed to nonsurname "Mc" marks) in fields that are far different than fast foods (for example, local family businesses ranging from dry cleaning to clothing sales) may have rendered the mark incapable of being diluted in unrelated fields. ${ }^{124}$ Similarly, extensive third-party use may preclude a dilution claim asserted by a local family business against a regionally famous junior user. ${ }^{125}$ Widespread prior third-party use increases the difficulty of establishing dilution under the distinctiveness prong. ${ }^{126}$ Nevertheless, when it is clear that the junior user adopted a similar mark to trade on the commercial magnetism of the famous mark, relief for dilution is more likely. ${ }^{127}$

This factor raises yet another fact-sensitive inquiry that will turn on the quantity and quality of evidence, and a survey or some other evidence of "actual dilution" caused by third-party use may be valuable. For example, if the defendant argues that plaintiff's mark is widely used, plaintiff may respond with evidence showing that the relevant consuming public is not aware of the thirdparty users. Alternatively, the third-party use may exist in markets or regions in which neither party operates. If so, and if plaintiff's mark is sufficiently famous and distinctive within the markets and areas in which the parties do operate, relief under section 43(c) may be available.

\section{B. The Intent Factor}

The federal statute specifically provides enhanced remedies where a defendant willfully intends to trade on the owner's goodwill or to cause the dilution of the mark. ${ }^{128}$ The federal statute is silent, however, about whether

122. 3 MCCARTHY, supra note $15, \S 24.17[1]$, at 24-137 (footnotes omitted).

123. See, e.g., McDonald's Corp. v. McBagel's, Inc., 1 U.S.P.Q.2d 1761 (S.D.N.Y. 1986) (holding that McBagel's for bagel restaurant dilutes McDonald's for chain of fast-food restaurants).

124. McDonald's has, however, been successful in asserting infringement claims beyond the restaurant industry based on its ownership of a non-surname "Mc" family of marks. See, e.g., Quality Inns Int'l, Inc. v. McDonald's Corp., 695 F. Supp. 198, 221 (D. Md. 1988) (holding that McSleep Inn for economy motels infringes and dilutes family of marks consisting of "Mc" prefix).

125. See Ernst Hardware Co. v. Ernst Home Ctr., 895 P.2d 1363, 1367 (Or. Ct. App.) ("[A]t least two other businesses in St. Paul, and perhaps two dozen others in Oregon, operate under the name Ernst."), rev. denied, 900 P.2d 509 (Or. 1995).

126. Accuride Int'l, Inc. v. Accuride Corp., 871 F.2d 1531, 1539 (9th Cir. 1989) ("[B]ecause 'Accu-' and 'Ride' are used by many others in trade names and trademarks ... [and] the parties' concurrent use of 'ACCURIDE' as a trademark for twenty-five years effectively precluded a finding that the value of 'ACCURIDE' trade name could be diluted.").

127. Cf. Eastman Kodak Co. v. Rakow, 739 F. Supp. 116, 119 (W.D.N.Y. 1990) ("Although bad faith is not a necessary element under [New York's dilution statute], it is relevant in assessing such a claim."); RESTATEMENT, supra note $5, \$ 25$ reporter's note ("[A]n intent to tarnish or to dilute the distinctiveness of another's mark may in some cases justify an inference that the intended harm has in fact occurred.").

128. See 15 U.S.C.A. \$1125(c)(2) (West Supp. 1996). 
bad faith enhances the likelihood of dilution, or, conversely, the lack of bad faith reduces the likelihood of dilution.

It is relatively clear that the deliberate adoption of a mark to trade upon the reputation and goodwill of another should be a strong, if not determinative, factor favoring a finding of dilution. ${ }^{129}$ It is reasonable to presume that a defendant is likely to accomplish the purpose of its intent. ${ }^{130}$ A more difficult question in the courts, particularly in the Second Circuit, is whether bad faith is a requirement for a dilution claim. ${ }^{131}$ The better view, as noted in the Restatement, is that "the intent of the defendant should not be balanced against factors relating to the market context of the use in order to determine the likelihood of dilution." 132 While it may be inferred that an actor is likely to bring about the intended result, the same is not true for the converse proposition. The absence of an intent to dilute has no bearing on whether use of a mark is likely to dilute.

\section{First Amendment and Fair Use Issues}

Section 43(c) by its specific terms does not apply to three types of conduct that raise substantial free speech and fair use issues: "Non-commercial use of a mark ... [; a]ll forms of news reporting and news commentary ... [; and] [f]air use of a famous mark ... in comparative advertising or promotion to identify the competing goods or services of the owner of the famous mark." 133

The lack of comparable exceptions led to the deletion of the proposed dilution section of the 1988 amendments to the Lanham Act, ${ }^{134}$ and the legislative history of the 1995 statute suggests that the exceptions are intended to respond to the concerns expressed by opponents who testified against the

129. See RESTATEMENT, supra note $5, \S 25 \mathrm{cmt}$. h ("[A] likelihood of dilution or tarnishment may be inferred if the actor has intentionally attempted to bring about [dilution or tamishment of the plaintiff's mark]."). In this regard, evaluation of the likelihood of dilution is analogous to a likelihood of confusion, in which "[i]ntent on the part of the alleged infringer to pass off its goods as the product of another raises an inference of likelihood of confusion." Squirtco v. Seven-Up Co., 628 F.2d 1086, 1091 (8th Cir. 1980).

130. See Osem Food Indus., Ltd. v. Sherwood Foods, Inc., 917 F.2d 161, 165 (4th Cir. 1990) ("Logic requires . . . that from such intentional copying arises a presumption that the newcomer is successful."); RESTATEMENT, supra note $5, \S 22 \mathrm{cmt}$. c ("[I]t may be appropriate to assume that an actor who intends to cause confusion will be successful in doing so.").

131. Compare W.W.W. Pharm. Co. v. Gillette Co., 984 F.2d 567, 576-77 (2d Cir. 1993) (explaining that court's test for dilution requires showing of bad faith and holding that SPORTSTICK for lip balm not diluted by RIGHT GUARD SPORT STICK for antiperspirant), with Deere \& Co. v. MTD Prods., 41 F.3d 39, 46 n.10 (2d Cir. 1994) (finding that intent is relevant but not a required element, and commenting that judicial analyses of the intent requirement in prior cases "may have resulted from an overreading of prior precedent").

132. RESTATEMENT, supra note 5, § 25 reporter's note. Again, dilution analysis is analogous to that for a likelihood of confusion, in which "[g]ood faith is not a defense to trademark infringement." Fuji Photo Film Co. v. Shinohara Shoji Kabushiki Kaisha, 754 F.2d 591, 596 (5th Cir. 1985); see also President \& Trustees of Colby College v. Colby College-N.H., 508 F.2d 804, 812 (1st Cir. 1974) ("[A] finding of good faith is no answer if likelihood of confusion is otherwise established.").

133. 15 U.S.C.A. $\$ 1125$ (c)(4)(A)-(C) (West Supp. 1996).

134. See H.R. REP. No. 104-374, supra note 11 , at 5-6. 
previous proposal. $^{135}$ Despite the apparent expectation that the federal statute creates safe harbors in certain free speech and fair use contexts, it is questionable whether these express limitations àctually enhance a defendant's rights or add to current First Amendment or fair use case law under state dilution statutes. Absent similar statutory exceptions, courts applying the state statutes have acknowledged consistently that First Amendment and fair use principles preclude application of a dilution statute (and other trade regulations) to prevent certain forms of expression. As a sponsor of the failed 1988 legislation noted, the desire for such express limitations may be misplaced: "[C]oncerns that a federal dilution provision will reach to the use of another's trademark in comparative advertising, satire, consumer reporting, and editorial comment are unfounded; by its nature, dilution does not and cannot reach to these 'fair uses' of another's trademark." 136

An analysis of dilution cases brought under state statutes demonstrates that the express exceptions in the federal statute may add nothing to existing law.

1. The Exemption for Non-commercial Use. "The exception for noncommercial use of a famous mark is intended to prevent courts from enjoining constitutionally-protected speech." ${ }^{137}$ Although no state dilution statute has a comparable express exception for non-commercial use of a mark, courts applying the state dilution statutes have balanced the First Amendment interests of a trademark "parodist" against the competing interests of the owner of the targeted mark. Judicial responses in cases involving free speech claims based on trademark parody have varied widely. ${ }^{138}$ But the fact that courts have

\footnotetext{
135. The House Report underlying the federal statute states:

The proposal adequately addresses legitimate First Amendment concerns espoused by the broadcasting industry and the media. The bill will not prohibit or threaten "noncommercial" expression, as that term has been defined by the courts. Nothing in this bill is intended to Id. at 4 . alter existing case law on the subject of what constitutes "commercial" speech.

136. S. REP. No. 100-515, supra note 53, at 41.

137. Panavision Int'l, L.P. v. Toeppen, CV 96-3284 DDP (JRX), 1996 WL 653726, at *6 (C.D. Cal. 1996).

138. See, e.g., Hormel Foods Corp. v. Jim Henson Prods., Inc., 73 F.3d 497 (2d Cir. 1996) (SPAM for lunch meat product not diluted by "Spa'am" for humorous puppet character); Balducci Publications v. Anheuser-Busch, Inc., 28 F.3d 769 (8th Cir.), cert. denied, 115 S.Ct. 903 (1994) (mock advertisement on back cover of humor magazine for "Michelob Oily" products dilutes MICHELOB for beer); Jordache Enters., Inc. v. Hogg Wyld, Ltd., 828 F.2d 1482 (10th Cir. 1987) (LARDASHE for jeans does not dilute JORDACHE for jeans); L.L. Bean, Inc. v. Drake Publishers, Inc., 811 F.2d 26 (1st Cir.), cert. denied and appeal dismissed, 483 U.S. 1013 (1987); Dallas Cowboys Cheerleaders, Inc. v. Pussycat Cinema, Ltd., 604 F.2d 200 (2d Cir. 1979) (use of trade dress substantially similar to that of the Dallas Cowboys cheerleaders dilutes); American Express Co. v. Vibra Approved Labs., 10 U.S.P.Q.2d 2006, 2012-13 (S.D.N.Y. 1989) (AMERICAN EXPRESS CARD mark and design diluted by "condom card" that copied substantial portions of plaintiff's marks); D.C. Comics, Inc. v. Unlimited Monkey Bus., Inc., 598 F. Supp. 110 (N.D. Ga. 1984) (use of "Super Stud" and "Wonder Wench" by singing telegram business dilutes SUPERMAN and WONDER WOMAN marks); Pillsbury Co. v. Milky Way Prods., 215 U.S.P.Q. 124 (N.D. Ga. 1981) (figures in publication resembling Pillsbury's "Poppin Fresh" and "Poppie Fresh" characters dilute the characters); Coca-Cola Co. v. Gemini Rising, Inc., 346 F. Supp. 1183 (E.D.N.Y. 1972) (ENJOY COCA-COLA diluted by ENJOY COCAINE on poster); Girl Scouts of U.S.A. v. Personality Posters Mfg. Co., 304 F. Supp. 1228 (S.D.N.Y. 1969) (GIRL SCOUTS not
} 
analyzed trademark parodies under the First Amendment suggests that the exception for non-commercial uses in section 43(c) is unlikely to enhance a defendant's First Amendment rights in cases brought under the federal statute because most free-speech dilution cases already turn on whether the defendant's use is "commercial" or "non-commercial."139 The difficult issue in litigation has not been whether non-commercial speech is protected (as recited in the safe harbor of section $43(\mathrm{c})(4)(B))$ but whether allegedly parodic use of a mark is commercial or non-commercial speech. ${ }^{140}$ Because many First Amendment dilution cases involve hybrid uses of marks (uses that have indicia of commercial and non-commercial speech), the answer to this question is complex. Generally, resolution of the First Amendment issue depends on whether the primary purpose of the use was to communicate a message and whether use of the trademark bears any relationship to the message. ${ }^{141}$

For example, in Dr. Seuss Enterprises, L.P. v. Penguin Books USA, Inc. ${ }^{142}$ the court accepted a non-commercial speech claim advanced in response to a dilution claim brought under the federal statute. Defendants conceived, wrote, and published a satirical work entitled The Cat Not in the Hat! A Parody by Dr. Juice, "a work poised to supply a 'fresh new look' at the O.J. Simpson double-murder trial." ${ }^{143}$ The text, illustrations, and packaging of defendants'

diluted by poster depicting pregnant girl wearing scouting uniform with the slogan "be prepared"). For commentary discussing the application of dilution statutes to speech claims, see Miles J. Alexander \& Michael K. Heilbronner, An Analysis of the Dilution Section of the Restatement, 47 S.C. L. REV. 630 (1996); Robert C. Denicola, Trademarks as Speech: Constitutional Implications of the Emerging Rationales for the Protection of the Trade Symbols, 1982 WIS. L. REV. 158 (1982); Robert J. Shaughnessy, Note, Trademark Parody: A Fair Use and First Amendment Analysis, 72 VA. L. REV. 1079 (1986).

139. A possible exception would be the emergence of a "new" class of non-commercial uses that do not involve a defendant's First Amendment speech interests. The same defendant in two cases brought under the federal statute has unsuccessfully claimed that the use of a famous mark as an Internet domain name is non-commercial use that is not susceptible to attack under the federal statute. In both cases, the courts determined that the defendant's adoption of a famous mark as an Internet domain name, for the purpose of re-selling the domain name to the owner of the famous mark, constitutes a commercial use of the mark. See Intermatic Corp. v. Toeppen, No. 96 C 1982, 1996 WL 716892, at *12 (N.D. Ill. Nov. 2, 1996) ("Toeppen's intention to arbitrage the "intermatic.com" domain name constitutes a commercial use."); Panavision, at *7 ("Permissible, non-trademark uses stand in sharp contrast to Toeppen's use of the Panavision marks. Toeppen traded on the value of the marks as marks by attempting to sell the domain names to Panavision."). The express exception for non-commercial uses might have made a material difference, however, had either court found that the defendant's use was non-commercial.

140. Commercial speech is speech that does no more than propose a commercial transaction. Bolger v. Youngs Drug Prods. Corp., 463 U.S. 60, 66 (1983). The test for determining the constitutionality of commercial speech has four parts: (1) whether the speech pertains to lawful activity and is not misleading; (2) whether the government has a substantial interest in taking the action that restricts the speech; (3) whether the government's action directly advanced the underlying interest; and (4) whether the government action was no more extensive than necessary to fulfill the interest. Central Hudson Gas \& Elec. Corp. v. Public Serv. Comm'n, 447 U.S. 557, 566 (1980).

141. For a more thorough discussion of the free speech issue in dilution cases and the propriety of the commercial speech doctrine as the proper test, see Alexander \& Heilbronner, supra note 138, at 649-55.

142. 924 F. Supp. 1559 (S.D. Cal. 1996)

143. Id. at 1561 . 
book were designed to "mimic the distinctive style of the family of works created by Theodor S. Geisel, better known as Dr. Seuss." ${ }^{144}$

In addition to copyright and trademark infringement claims, plaintiff alleged that defendants' use of seven trademarks was likely to dilute the distinctiveness of the marks under the federal dilution statute. ${ }^{145}$ Defendants claimed that its book was a non-commercial parody expressly exempt from a dilution claim under the federal statute. ${ }^{146}$ According to the court, "Dr. Seuss replie[d] that [defendants'] use cannot be accepted as 'non-commercial' because the marks were used 'to make their book more entertaining and to consequently, sell more copies."'147 Rejecting this argument, the court held that defendants' expressive use of the Dr. Seuss marks "is not rendered commercial by the impact of the use on sales." 148 Accordingly, defendants' use of the Dr. Seuss marks was exempt from the reach of section 43(c).

Arguably, the court's analysis of the defendants' First Amendment defense to plaintiff's trademark infringement claim suggests that the express exception for non-commercial speech in section 43(c) does expand the parodist's rights beyond those that exist under state dilution statutes. ${ }^{149}$ Considering plaintiff's trademark infringement and unfair competition claims, the court found that the non-commercial nature of defendants' use was insufficient, absent a statutory exception, to prevent an injunction under the trademark infringement and unfair competition provisions of the Lanham Act. ${ }^{150}$

Because the First Amendment analysis led to different results under plaintiff's federal dilution claim and its infringement and unfair competition claims, the statutory exception in 43(c) may operate to expand the speech rights of a trademark parodist. Unlike infringement and unfair competition claims, however, dilution claims do not implicate the public policy against consumer confusion. For infringement claims involving trademark parody, the public interest in avoiding potential confusion must be balanced against the parodist's free speech interests. This factor does not arise under a dilution claim, which only involves the potential erosion of the trademark owner's rights in a mark. Thus, the distinction between the interests at stake in dilution and infringement claims, rather than the express exception for non-commercial speech contained

144. Id.

145. Id. at 1573-75 Some of the allegedly misappropriated marks included the DR. SEUSS mark, the THE CAT IN THE HAT mark; the design mark consisting of an illustration of The Cat in the Hat character, and the design mark of the cat's stove pipe hat. Id. at 1570.

146. Id. at 1573-74.

147. Id. at 1574.

148. Id. at 1574 (citing Virginia Pharmacy Bd. v. Virginia Citizens Consumer Council, Inc., 425 U.S. 748,762 (1975) (stating that commercial speech is "speech which does no more than propose a commercial transaction")); see also id. at 1572 ("Even if the use would also increase the sales of the commentary, the use remains noncommercial.").

149. See id at 1571-73.

150. Id. at 1573 ("Just as in copyright, trademark infringement will be excused only where necessary to the purpose of the use. Where alternative means of achieving the satiric or parodic ends exist that would not entail consumer confusion, the First Amendment will not protect the parodist from being held to infringe." (footnotes omitted)). 
in the federal statute, may explain the different results reached by the $D r$. Seuss court.

Generally, courts applying state dilution statutes that do not contain statutory exceptions for non-commercial speech have used the commercial/noncommercial distinction to determine whether the First Amendment precluded application of the statute to a parodic use of a mark. In Anheuser-Busch, Inc. v. Balducci Publications, ${ }^{151}$ the Eighth Circuit rejected a First Amendment defense after defendant published a fake advertisement for MICHELOB OILY beer on the back cover of a humor magazine. Several factors influenced the result: The advertisement parody was placed where real advertisements are routinely located, ${ }^{152}$ and the advertisement included "only a tiny disclosure" that the advertisement was an editorial parody. ${ }^{153}$ The advertisement also suggested that Anheuser-Busch's products were contaminated with oil, ${ }^{154}$ and the attack was not necessary to defendant's alleged free speech goals of commenting on the Gasconade oil spill and water pollution generally. ${ }^{155}$ Consequently, the court found that defendant's alleged parody was more an attempt to appropriate the commercial magnetism of the MICHELOB mark for commercial purposes than an attempt to convey a message.

In contrast, in L.L. Bean, Inc. v. Drake Publishers, Inc., ${ }^{156}$ the court overturned an injunction against the publisher of "High Society" magazine for its sexual parody of plaintiff's catalogs and held that the First Amendment prevented application of dilution statutes to the use of a mark in a noncommercial speech setting. ${ }^{157}$ The parody consisted of a few pages inside a magazine. The court found that defendant's use of "L.L. Beams Sex Catalogue" was non-commercial largely because defendant did not seek to merchandise its products under the guise of trademark parody, and it was likely that consumers would understand the parodic message. ${ }^{158}$

In Deere \& Co. v. MTD Prods., Inc., ${ }^{159}$ the Second Circuit also focused on the commercial nature of a manufacturer's use of John Deere's drawn "deer logo" in a commercial for lawn tractors:

Sellers of commercial products who wish to attract attention to their commercials or products and thereby increase sales by poking fun at widely recognized marks of noncompeting products, risk diluting the selling power of the mark that is made fun of. When this occurs, not for worthy purposes of expression, but simply to sell products, that purpose can easily be achieved in other ways. The potentially diluting

151. 28 F.3d 769 (8th Cir. 1994), cert. denied, 115 S.Ct. 903 (1995).

152. Id. at 776 .

153. Id. at 778.

154. Id.

155. Id.

156. 811 F.2d 26 (1st Cir.), cert. denied, 483 U.S. 1013 (1987).

157. Id. at $30-31$.

158. Id. at $32-33$ (noting, inter alia, that the article was labelled as "humor" and "parody," and neither the article nor the mark appeared on the front or back cover of the magazine).

159. 41 F.3d 39 (2d Cir. 1994). 
effect is even less deserving of protection when the object of the joke is the mark of a directly competing product. ${ }^{160}$

As indicated by these cases, the commercial or non-commercial distinction is not amenable to a bright-line standard. "Hybrid" cases involving speech with commercial and non-commercial attributes make for difficult decisions. By way of example, a parody of machine guns and the National Rifle Association, if used by a public interest group on T-shirts to raise money in support of a campaign for stricter gun control laws, may straddle the line dividing commercial and non-commercial speech. The content of the parody is clearly expressive speech, and the commercial aspects of the sale of the T-shirts may give way to the non-commercial political speech or charitable use of the funds. ${ }^{161}$ In contrast, a parody might present a more difficult commercial speech issue if the parody is used by a for-profit enterprise whose only goal is to capitalize on the commercial magnetism of the National Rifle Association's mark. ${ }^{162}$ Accordingly, because the First Amendment already protects non-commercial speech, the exception in section 43(c) probably will have little effect, nor will it refine or clarify the outcome of such litigation arising under the federal statute. ${ }^{163}$

2. The News Reporting Exception. The express exception for news reporting is also unlikely to have a significant effect on the outcome of disputes arising under section 43(c). As an initial matter, dilution challenges against news agencies are extremely rare. ${ }^{164}$ Moreover, under circumstances analogous to the application of a dilution statute, courts have determined that news reporting and related speech are protected by the First Amendment if the use is not primarily for a commercial purpose. ${ }^{165}$ Thus, even if a federal dilution

160. Id. at 44-45 (citations omitted).

161. See Stop the Olympic Prison v. United States Olympic Comm., 489 F. Supp. 1112, 1121 (S.D.N.Y. 1980) (holding that the use of "Stop the Olympic Prison" on poster by organization protesting use of the Olympic village as prison did not violate the Act because "[t]he poster was not used 'for the purpose of trade,' or 'to induce the sale of any goods or services, or to promote any theatrical exhibition, athletic performance or competition"' (quoting the Amateur Sports Act of 1978, 36 U.S.C. $\S 371$, which restricts use of the term "Olympic")).

162. See Coca-Cola Co. v. Gemini Rising, Inc., 346 F. Supp. 1183 (S.D.N.Y. 1972) (finding that "Cocaine Cola" in distinctive script on posters dilutes ENJOY COCA-COLA). Query whether a different result would arise out of a similar use of "caffeine" in connection with Coca-Cola's famous script lettering by a public interest health group as part of a fundraising campaign.

163. The exception may have an educational effect for courts that have not addressed First Amendment issues in cases that appear to involve difficult free speech questions.

164. The authors are unaware of a published decision involving a dilution suit challenging news reporting.

165. See New Kids on the Block v. News Am. Publ'g, Inc., 745 F. Supp. 1540, 1545 (C.D. Cal. 1990) (discussing trademark infringement and misappropriation claims and finding magazine's and newspaper's use of NEW KIDS ON THE BLOCK mark in connection with public opinion poll was related to news-gathering function, and, therefore, protected under First Amendment ), aff'd, in part, on other grounds, 971 F.2d 302 (9th Cir. 1992) (affirming summary judgment on trademark infringement claim under fair use principles without reaching First Amendment issue; affirming summary judgment of misappropriation claims under First Amendment news-gathering defense); Montana v. San Jose Mercury News, Inc., 40 Cal. Rptr. 2d 639 (Ct. App. 1995) (discussing common law misappropriation and holding sale of poster depicting newspaper pages containing photograph and drawing of famous football player to be in connection with newspaper's news-gathering function, and, therefore, not actionable). 
challenge is brought against a news agency, the case would likely be subject to similar First Amendment limitations absent the express exception in the federal statute. The difficult issue is not whether news-related use of a mark is protected, but whether the use fulfills the purposes of news-gathering and dissemination or is merely a pretext for traditional commercial activity.

The statutory exception may expand existing law in marginal cases in which the news agency's use is only minimally related to news reporting. The Supreme Court has held that the First Amendment does not require absolute immunity in favor of the media's news-gathering function. ${ }^{166}$ Rather, the government may provide relief based on a news agency's complete appropriation and depletion of the "commercial stake" in a venture. ${ }^{167}$ On the other hand, the government is also free to provide more protection for the press than is provided by the First Amendment. ${ }^{168}$ Under this authority, it is arguable that the exception in the federal statute goes beyond the constitutional requirements of the First Amendment by protecting use of a mark that fulfills any aspect of the news-gathering function, regardless of its commercial purpose.

3. The Comparative Advertising Fair Use Exemption. Similarly, the federal dilution statute's express exception for fair use in comparative advertising probably adds little to existing law. Courts have already determined that dilution statutes do not apply to fair use in comparative advertising ${ }^{169}$ and in other related contexts. ${ }^{170}$

Once again, the difficult issue is not whether fair use is protected, as recited in section 43(c), but whether the challenged use of a mark constitutes "fair use."

166. Zacchini v. Scripps-Howard Broad. Co., 433 U.S. 562, 578 (1977) (right of publicity) (stating that First Amendment does not require absolute immunity for news broadcast of entertainer's entire performance and that state may provide a remedy to protect the full value of the commercial "stake" in an entertainer's act).

167. Id.

168. Id. ("[A]lthough the State of Ohio may as a matter of its own law privilege the press in the circumstances of this case, the First and Fourteenth amendments do not require it to do so.").

169. Deere \& Co. v. MTD Prods., Inc., 41 F.3d 39, $44-46$ (2d Cir. 1994) (noting that New York's dilution statute does not apply to prevent fair use in comparative advertising, but holding that competitor's alteration and use of an animated version of John Deere's drawn deer logo was not a fair use).

170. See Institute for Scientific. Info. v. Gordon \& Breach, 931 F.2d 1002 (3d Cir. 1991) (descriptive use of mark) (acknowledging the fair use issue raised by owner's allegations of CURRENT CONTENTS for a journal for information retrieval services that defendant's use of "current contents" as part of sub-heading of similar journal was not fair use and diluted plaintiff's mark); Munters Corp. v. Matsui Am., Inc., 730 F. Supp. 790, 802 (N.D. Ill. 1989) (non-trademark, descriptive use of "honeycomb" to describe shape of component of product) ("The purpose of this [dilution] Act is presumably not to stifle the non-trademark use of descriptive words."), aff'd, 909 F.2d 250, cert. denied, 498 U.S. 1016 (1990); Gear, Inc. v. L.A. Gear Cal., Inc., 670 F. Supp. 508, 520 (S.D.N.Y. 1987) (fair use of allegedly generic term) (explaining that defendant's use of mark "L.A. GEAR" for "athleisure" wear and footwear does not dilute plaintiff's mark "GEAR" for apparel because "gear" is generic as applied to apparel, but that issues of fact remain as to whether "gear" is generic for handbags and soft luggage); see also New Kids on the Block v. News Am. Pub., 971 F.2d 302, 306 (9th Cir. 1992) (dilution not at issue) ("[I]t is often virtually impossible to refer to a particular product for purposes of comparison, criticism, point of reference or any other such purpose without using the mark."). 
Factors in this determination may include, inter alia, whether the use is in good faith ${ }^{171}$ "the degree to which the mark is altered and the nature of the alteration," ${ }^{172}$ whether the mark is being used in a descriptive sense, ${ }^{173}$ and whether plaintiff's mark is used to identify defendant's product or in a generic sense. ${ }^{174}$ The generic use problem arose in Sykes Laboratories., Inc. $v$. Kalvin ${ }^{175}$ where the court determined that a genuine issue of material fact existed as to whether defendant's label for a fingernail conditioner, which stated that defendant's product was a "version" of SYKES PERFECT NAIL, constituted a fair use comparison that identified the defendant's product or was a generic use of the SYKES PERFECT NAIL mark. ${ }^{176}$

\section{Is Tarnishment Covered?}

The legislative history of section 43(c) indicates unequivocally that the federal statute is intended to encompass an action for tarnishment. ${ }^{177}$ Despite congressional intent, however, the federal statute defines dilution in terms of the "blurring" prong of the doctrine (diminution of distinctiveness), but not explicitly in terms of "tarnishment" (interference with positive images): "The term 'dilution' means the lessening of the capacity of a mark to identify and distinguish goods or services, regardless of the presence of absence of [competition or confusion.]"178 As the Dr. Suess court stated: "The Act explicitly bars dilution through loss of distinctiveness. The legislative history supports the

171. See Ringling Bros.-Barnum \& Bailey Combined Shows, Inc. v. Celozzi-Ettelson Chevrolet, Inc., 855 F.2d 480, 483-84 (7th Cir. 1988) (stating that the "fair use defense requires good faith" and holding that THE GREATEST USED CAR SHOW ON EARTH for auto dealership dilutes THE GREATEST SHOW ON EARTH for circus).

172. Deere, 41 F.3d at 45 (conversion of John Deere's drawn "deer logo" into small, scared animal not fair use); see also New Kids On the Block, 971 F.2d at 308 n.7 (dicta) ("[A] soft drink competitor would be entitled to compare its product to Coca-Cola or Coke, but would not be entitled to use CocaCola's distinctive lettering." (citation omitted)); Volkswagenwerk Aktiengesellschaft v. Church, 411 F.2d 350, 352 (9th Cir. 1969) ("Church did not use Volkswagen's distinctive lettering style or color scheme, nor did he display the encircled 'VW' emblem.").

173. Ringling Bros., 855 F.2d at 484 ("If Celozzi-Ettelson had used the slogan The Greatest Used Car Showroom on Earth it might have had a plausible argument that its slogan was laudatory and descriptive; but it used the word Show, not Showroom, and, unlike the circus, the used car business is not literally a show.").

174. Sykes Lab., Inc. v. Kalvin, 610 F. Supp. 849, 859 (C.D. Cal. 1985) (involving comparative reference to competitor's nail conditioning product) ("The anti-dilution statute in no way restricts the right to advertise a claim that one's product is as good as a better known brand, but one may not do it in a way that risks turning the latter into a generic term.").

175. Id.

176. Perhaps, the defendant could have avoided the issue altogether by referencing the SYKES PERFECT NAIL product as follows: "Compare to SYKES PERFECT NAIL brand nail conditioner."

177. H.R. REP. NO. 104-374, supra note 11, at 2 ("HR 1295 is designed to protect famous trademarks from subsequent uses that blur the distinctiveness of the marks, or tarnish or disparage it."). The only examples of dilution in the legislative history, however, are examples of dilution by blurring. Id. at 3 (DUPONT shoes, BUICK aspirin, and KODAK pianos). One court has considered identical examples under the blurring prong only. Hormel Foods Corp. v. Jim Henson Prods., 73 F.3d 497, 506 (2d Cir. 1996) ("The legislative history of [the New York statute gives] examples of hypothetical [blurring] violations: 'DuPont shoes, Buick aspirin .....") (quoting 1954 N.Y. Legis. Ann. 49-50).

178. 15 U.S.C.A. $\S 1127$ (West Supp. 1996) (emphasis added). 
conclusion that Congress also intended the Act to cover dilution through tarnishment." 179

According to the legislative history of the federal statute, however, the statutory definition of dilution "is designed to encompass all forms of dilution recognized by the courts, including dilution by blurring, by tarnishment, and disparagement." ${ }^{180}$ The conclusion that blurring language encompasses tarnishment is consistent with the authors' view that tarnishment is merely an enhanced form of blurring. The mental association necessary for blurring occurs, but with tarnishment it occurs in a negative context that furthers the injury to the commercial magnetism of a mark. Likewise, courts considering tarnishment claims brought under the federal statute have uniformly assumed that section $43(\mathrm{c})$ covers a tarnishment claim. ${ }^{181}$

Arguably, however, if the classic case of tarnishment does not lessen the capacity of a mark to identify and distinguish goods or services, the definition of "dilution" in the federal statute does not achieve the congressional intent to cover tarnishment. Several courts have held that rather than reducing the exclusive association between the mark and the owner's goods and services, tarnishing uses of a mark may actually increase public identification, and, therefore, do not violate the blurring prong. ${ }^{182}$

In defining "dilution," Congress appears to assume that both dilution and tarnishment are covered by the blurring language of the federal statute. Yet, it can be argued that this assumption is misplaced. Most state statutes protect specifically against "injury to business reputation," 183 but the federal statute has no comparable language. If the tarnishment prong of dilution is based on the "injury to business reputation" language, relief for tarnishment is arguably not available under the federal statute. ${ }^{184}$

179. Dr. Suess Enters., L.P. v. Penguin Books USA, Inc., 924 F. Supp. 1559, 1573 (S.D. Cal. 1996) (citations omitted).

180. H.R. REP. NO. 104-374, supra note 11 , at 8 (emphasis added).

181. See, e.g., Toys "R" Us, Inc. v. Akkaoui, 40 U.S.P.Q.2d 1836 (N.D. Cal. 1996) ("TOYS R' US and KIDS R' US for children's retail stores tarnished by ADULTS R' US for on-line provider of sexual devices and clothing); Hasbro, Inc. v. Internet Entertainment Group, Ltd., 40 U.S.P.Q.2d 1479 (W.D. Wash. 1996) (CANDYLAND for board game tarnished by CANDY LAND and CANDYLAND.COM domain name for sexually explicit Internet site).

182. Hormel Foods Corp. v. Jim Henson Prods., 73 F.3d 497, 506 (2d Cir. 1996) (citing Jordache Enters., Inc. v. Hogg Wyld, Ltd., 828 F.2d 1482, 1490 (10th Cir. 1987)); Tetley, Inc. v. Topps Chewing Gum, Inc., 556 F. Supp. 785, 794 (E.D.N.Y. 1983) (explaining that humorous use of another's mark "serve[d] to prevent the type of blurring which might result from a more subtle or insidious effort at humor at plaintiff's expense"); see also RESTATEMENT, supra note $5, \S 25 \mathrm{cmt}$. i ("In most instances such uses are intended to refer back to the original trademark owner and serve to confirm rather than undermine the associational significance of the mark.").

183. But see Connecticut, South Carolina, and Washington statutes, supra nnote 15 , which, like the amended dilution section of the Model State Trademark Bill, define dilution in the same terms as the federal statute.

184. Professor McCarthy contends that traditional blurring language subsumes tarnishment and that the "injury to business reputation" language does not define a separate harm:

In the author's opinion, the phrase "injury to business reputation" does not stand alone as an alternative to "dilution of the distinctive quality of a mark," but the [state] statute[s] must be read as if [they] said "injury to business reputation ... of the distinctive quality of a mark." 
Some courts have relied on the "injury to business reputation" language of state dilution statutes when evaluating a tarnishment claim. ${ }^{185}$ Additionally, Schechter originally conceived dilution to remedy injuries caused by blurring, not tarnishment: "The real injury ... is the gradual whittling away or dispersion of the identity and hold upon the public mind of the mark or name by its use on non-competing goods." 186 Also, the Trademark Review Commission originally drafted separate provisions for the blurring and tarnishment prongs of dilution. ${ }^{187}$

. . [T] he two concepts should be read as synonymous.

3 MCCARTHY, supra note $15, \S 24.14$ [2], at $24-124$ to $24-125$. Other commentators suggest that the statutory distinction between blurring and tarnishment is a matter of linguistics that should not occupy a significant amount of a court's time. See Rochelle D. Alpert \& Matthew K. Fawcett, New Federal Trademark Dilution Act in a Nutshell, THE INTELL. PrOP. STRATEgIST, Feb. 1996, at 8 ("It is unlikely, however, that this semantic difference will have a practical effect once courts interpret the Act."); Mark S. Sommers, The New US Trademark Dilution Act: Problems Lurking?, TRADEMARK WORLD, Feb. 1996, at 19 ("Given the legislative history of the Act and its definitional identity with INTA's model bill, courts confronted with a classic tarnishment case will likely find it covered by the new Act.").

The District Court of Connecticut has found that tarnishment is actionable under Connecticut's dilution statute even though it does not contain the "injury to business reputation" language. See, e.g., Private Eyes Sunglass Corp. v. Private Eye Vision Center of New Milford, 25 U.S.P.Q.2d 1709, 1719 (D. Conn. 1992) (explaining that Connecticut's statute is "comparable" to the New York statute containing "injury to business reputation" language: "Connecticut statute [includes] the element that there be a "likelihood of dilution by a whittling down, blurring or tarnishment"), aff' d, 992 F.2d 321 (2d Cir. 1993) (citation omitted).

185. For example, the court in Accuride Int'l, Inc. v. Accuride Corp., 871 F.2d 1531, 1538 (9th Cir. 1989 ) affirmed the lower courts separate consideration of the "injury to business reputation" language that is "typically invoked where the plaintiff's mark or name is tarnished":

[Plaintiff] argues that the district court focused exclusively on dilution and simply failed to address

the likelihood of injury to business reputation. This argument is not supported by the record. . .

[T] he district court did consider, and reject, the appellants' contention regarding the "injury to business reputation" prong of [California's dilution statute].

Id. (emphasis added); see also Community Fed. Sav. \& Loan Ass'n v. Orondorff, 678 F.2d 1034, 1036 n.5, 1037 (11th Cir. 1982) (stating "[w]e are satisfied that [plaintiff's minimal evidence] is insufficient evidence of injury to [plaintiff's] business reputation," but finding that other evidence is a "potent witness[] to the actual or likely 'whittling away' of the unique character of [plaintiff's] mark"); E. \& J. Gallo Winery v. Consorzio Del Gallo Nero, 782 F. Supp. 457, 469 (N.D. Cal. 1991) (“[W]hile 'tarnishment' is required in showing a 'likelihood of injury to business reputation' under the first prong ...., the second prong 'is directed at protecting an owner's right to strong, well recognized marks."'); Munters Corp. v. Matsui Am., Inc., 730 F. Supp. 780, 801 (N.D. Ill. 1989) (citations omitted) ("The court must issue an injunction if: 1) the prior user shows a likelihood of injury to reputation; or 2) the prior user shows that ... the subsequent users' use dilutes [the] distinctiveness." (citations omitted)).

186. Schechter, supra note 20, at 825, 830-31. But see supra text accompanying notes 28-29 (discussing Schechter's proposed Perkins bill, which was designed to prevent general injuries to the trademark owner's goodwill and reputation).

187. The Commission expressly excluded tarnishment from coverage of $\S 43(\mathrm{c})$ and, instead, drafted a separate section: "The Commission believes that trademark tarnishment and disparagement are a separate form of legal wrong, and recommends amending Section $43(\mathrm{a})$ to deal with them." Id. at 455 n.134; see also id. at 434 ("[A] separate legal basis for relief will remove the need to apply legal doctrines which do not fit. We propose adding a new Section 43(a)(3) specifically to cover disparagement and tarnishment."). However, the Commission suggested that blurring language encompasses tarnishment because tarnishment affects a mark's distinctiveness: "Although tarnishment can dilute trademark distinctiveness, the typical injury is less dilution than injury to reputation." TRC Report, supra note 46, at 434 (emphasis added). During congressional hearings, the Senate Judiciary Committee amended the Commission's proposal of a separate tarnishment section by deleting "language making trademark tarnishment and disparagement a separate statutory cause of action." S. REP. NO. 
The Restatement also suggests that blurring and tarnishment may be legally distinct. Sections 25(1)(a) and 25(1)(b) of the Restatement ${ }^{188}$ are separate provisions describing blurring and tarnishment as the types of harm that can lead to liability without proof of confusion. The commentary to section 25 also addresses each concept separately. ${ }^{189}$ Although comment $c$ to section 25 of the Restatement states that "tarnishment and dilution of distinctiveness . . both undermine the selling power of a mark," the Comment refers to them separately and identifies them as "two distinct threats" that are "conceptually distinct." Thus, arguably, while blurring and tarnishment undermine the selling power of a mark, they may do so in different ways: blurring, by reducing distinctiveness, ${ }^{191}$ and tarnishment, by interfering with the positive images associated with the mark, an injury that may occur independently of injury to the distinctiveness of a mark. ${ }^{192} \quad$ In light of several Supreme Court holdings that the "clear language" of the Lanham Act should be applied, ${ }^{193}$ it would not be surprising to find counsel arguing that if the "injury to business reputation" language is the statutory basis for a tarnishment action under state law, the absense of such language from the federal statute precludes a claim for tarnishment under the Lanham Act. Such arguments may be unsuccessful, however, because, in some contexts, courts have ignored the plain language of the Lanham Act and defer to congressional intent. ${ }^{194}$

Justice Scalia stated recently that "[i]t is the law that governs, not the intent of the lawgiver." 195 Under a strict constructionist view like Justice Scalia's, the omission in the federal statute of the "injury to business reputation" language

$100-515$, supra note 53 , at 41 . Although this change probably reflected the belief that $\S 43(\mathrm{c})$ encompassed tarnishment, a strict construction of the federal statute may defeat congressional intent.

188. RESTATEMENT, supra note $5, \S 25(1)(\mathrm{a})$-(b).

189. Compare id. $\S 25 \mathrm{cmt}$. $\$(1)(\mathrm{a})$, with id. cmt. $\S(1)(\mathrm{b})$.

190. Id. cmt. c.

191. Id.

192. Id. cmt. g.

193. See Park 'N Fly, Inc. v. Dollar Park \& Fly, Inc., 469 U.S. 189, 197-98 (1985) ("Nothing in the legislative history of the Lanham Act supports a departure from the plain language of the statutory provisions concerning incontestability."); Fleischman Distilling Corp. v. Maier Brewing Co., 386 U.S. 714, 719 (1967) (reversing Ninth Circuit's creation of extra-ordinary remedy holding that, "[I]n the Lanham Act, Congress meticulously detailed the remedies available . . . [and] other remedies should not readily be implied."); see also Warnervision Entertainment, Inc. v. Empire of Carolina, Inc., 919 F. Supp. 717, (S.D.N.Y. 1996) (interpreting narrowly § 7(c) of the Lanham Act, 15 U.S.C. § 1057(c) (1994), to find that intent-to-use applicant-but not registrant-was not entitled to rely on application filing date to establish constructive use for priority purposes).

194. For example, $\$ 43$ (a) entitles "any person who believes that he or she is likely to be damaged by such acts [that cause a likelihood of confusion or a misrepresentation in advertising]" to bring a cause of action. 15 U.S.C. $\S 1125(\mathrm{a})(1)(\mathrm{B})$ (1994) (emphasis added). Notwithstanding this seemingly clear language, courts regularly hold that consumers lack a sufficient commercial interest to bring a cause of action under the statute. See Serbin v. Ziebart Int'l Corp., 11 F.3d 1163, 1164-65 (3d Cir. 1993) (providing an extensive history of consumer-standing cases, and determining that consumers lack standing even though "[s]ection $43(\mathrm{a})$ is, as a matter of syntax, sufficiently broad to accommodate consumer claims").

195. ANTONIN SCALIA, A MATTER OF INTERPRETATION: FEdERAL COURTS AND THE LAW 17 (1996). 
that is contained in most state dilution statutes may mean that a claim for tarnishment is not available under the federal statute.

Thus, there appears to be a viable argument that a claim for tarnishment is not available under the federal statute. To date, courts considering claims for tarnishment under section 43(c) have not been troubled by the possibility that the statutory definition of dilution may not cover tarnishment. ${ }^{196}$ Of course, the authors are unaware of a case in which a litigant has raised the issue. In light of the uncertainty surrounding the argument, it remains to be seen whether future litigants will challenge this aspect of the federal statute.

\section{E. The Federal Statute Applies to Registered and Unregistered Marks}

A preliminary version of section 43(c) was amended in the House to remove the limitation of the coverage of the proposed statute to registered marks. A similar restriction was included in the 1987 proposal for a federal statute. The amendment of the federal statute was proposed in the belief that limiting the statute to registered marks would undercut the United States's foreign trade position that famous marks should be protected regardless of whether they are registered in the country where protection is being sought. ${ }^{197}$

Use of a mark is a condition precedent to obtaining trademark rights in the United States, and the damage caused by dilution is based on diminution in distinctiveness and goodwill that has been developed through use. As a practical matter, the amendment makes sense because it provides protection to unregistered marks that become famous "overnight." Such marks may be the subject of registration applications that have not matured into registrations only because of delays in the Patent and Trademark Office. Generally, it takes at least a year to obtain a federal registration. Although it is sound policy to encourage federal registration as early as possible, there is no doctrinal reason why a registration should be necessary for federal dilution protection. ${ }^{198}$

\section{F. Federally Registered Marks are Immune From Liability Under State Statutes}

Under section 43(c), ownership of a federal registration is a bar to an action brought against the registrant under state statutory or common law dilution theories. ${ }^{199}$ This exception is intended to encourage federal registration ${ }^{200}$ and to provide security to federal registrants that develop national brand management strategies: "The commission . . . recommend[s] a provision making a federal registration a complete defense to an action under a state dilution law.

196. See supra note 181 and accompanying text.

197. H.R. REP. No. 104-374, supra note 11 , at 4.

198. With two exceptions, state dilution statutes also do not require a state trademark or service mark registration. See CONN. GEN. STAT. ANN. § 35-11a(11) (West 1987); S.C. CODE ANN. § 39-151105(2) (Law. Co-op. 1976).

199. See 15 U.S.C.A. $\$ 1125$ (c)(3) (West Supp. 1996).

200. H.R. REP. No. 104-374, supra note 11, at 7. 
This approach would accord registrants additional security in expansion situations while not unduly restricting the operation of state law."201 The federal statute fulfills this goal by providing federal registrants with a defense to dilution claims against all other trademark owners except those whose marks qualify for protection under section 43(c) (that is, owners of marks that were famous at the time the registrant began using its mark).

The exception for federal registrants increases the significance of opposition and cancellation actions in the Patent and Trademark Office, and trademark owners are likely to become more vigilant in monitoring publications for opposition. Because of the federal registration exception, opposition actions may be initiated even in cases where the likelihood of confusion is a close call. Likewise, as a preemptive strike against immunity to state law claims based on a federal registration, trademark owners also may be more likely to bring state dilution challenges in court prior to the issuance of a registration.

Congress did not add "dilution" as a basis for opposing or cancelling a registration. ${ }^{202}$ The Trademark Review Commission considered but ultimately rejected a provision that would have made dilution a basis for opposing and cancelling registrations:

We considered whether a registrant entitled to dilution relief by way of injunction would be able to prove the requisite damage under Sections 13 and 14 to sustain an opposition or cancellation proceeding. On the one hand, it would be illogical to provide for injunctive relief but not the ability to prevent or cancel a diluting registration. On the other, extending the Board's jurisdiction to an entirely new category of claims with attendant administrative problems, expense, and uncertainty, should not be undertaken lightly. On balance, we believe the courts should make the determination of "damage" here, based on all of the factors, as they have in the past. ${ }^{203}$

\section{G. Does the Federal Statute Apply to Competitors?}

As with all state dilution statutes, section 43(c) purports to apply "regardless of the presence or absence of (1) competition between the owner of the famous mark and other parties, or ... (2) likelihood of confusion, mistake, or deception." 204 Despite the apparent clarity of this language, some federal courts applying virtually identical language in the Illinois, Florida, and Oregon statutes have held that these state dilution statutes do not apply to competitors. ${ }^{205}$

201. TRC Report, supra note 46, at 458 ; see also id. at 462 ("Trademark owners require the assurance that once they have obtained federal registration, they are generally free to market their goods or services throughout the United States, subject only to prior rights in a confusingly similar mark.").

202. Babson Bros. v. Surge Power Corp., 39 U.S.P.Q.2d 1953, 1955 (T.T.A.B. 1996) (denying motion to add claim for dilution under federal statute as basis for opposition to registration and finding that federal statute does not create a new ground for opposition). An opposition or cancellation action can be brought only on specific grounds enumerated in $\S \S 2,13$, and 14 of the Lanham Act, 15 U.S.C. $\S \S 1052,1063$, and 1064 (1994).

203. TRC Report, supra note 46 , at 462.

204. 15 U.S.C.A. \& 1127 (West. Supp. 1996).

205. See AHP Subsidiary Holding Co. v. Stuart Hale Co., 1 F.3d 611 (7th Cir. 1993) (Illinois statute does not prevent dilution by a competitor). The Illinois statute applies "notwithstanding the absence of competition between the parties." ILL. ANN. STAT. ch. 765, para. 1035/15 (Smith-Hurd 1993) 
These decisions have contributed to dissatisfaction of some trademark owners over inconsistent interpretations of state dilution statutes.

The federal statute is likely to alleviate these concerns because the federal courts in Illinois, Florida, and Oregon are unlikely to follow state law precedent that is inconsistent with the clear language of the federal statute. Federal courts in other jurisdictions have had little difficulty applying the federal statute to competitors, ${ }^{206}$ and no court has questioned whether the federal statute applies to competitors. Additionally, because Illinois federal court decisions derive from state court interpretations of the Illinois statute, ${ }^{207}$ they are not binding precedential authority under the federal statute. The one Florida case, E.R. Squibb \& Sons, Inc. v. Princeton Pharmaceutical, Inc., is anomalous in light of clear holdings to the contrary from Florida state courts and from decisions of other Florida federal courts. ${ }^{208}$ Finally, in Soloflex, Inc. v. Nordictrack, Inc., the Oregon federal court based its holding on its asserted inability to find a case on point. The clear language and legislative history of the federal statute, as well as the views of the Trademark Review Commission and leading commentators, should be sufficient to remove any doubt that the federal statute applies to competitors.

\section{IV \\ CONCLUSION}

The myriad of doctrinal and statutory issues discussed in this article may raise as many questions as they answer, leaving ample opportunity for dispute as to the meaning and effect of the federal statute. In addition to these issues, the adoption of the federal dilution statute will likely lead to developments in

(emphasis added). The Oregon statute also applies "notwithstanding the absence of competition between the parties." OR. REV. STAT. $\$ 647.107$ (1988) (emphasis added). But see Soloflex, Inc. v. Nordictrack, Inc., 31 U.S.P.Q.2d 1721, 1731-32 (D. Or. 1994) ("Although there are no cases directly on point, Oregon law appears to limit trademark dilution claims to noncompetitors."). See also E.R. Squibb \& Sons, Inc. v. Princeton Pharm., Inc., 17 U.S.P.Q.2d 1447, 1454 (S.D. Fla. 1990) ("Florida's Anti-Dilution statute does not apply when the parties provide similar goods."). The language of the Florida statute is similar to the Illinois and Oregon statutes, and the basis for the court's statement is unclear, particularly in light of contrary Florida state cases. See Blanding Automotive Ctr. v. Blanding Automotive, 568 So.2d 490 (Fla. Dist. Ct. App. 1990) (finding auto repair business diluted competitor's mark); Tio Pepe, Inc. v. El Tio Pepe de Miami Restaurant, Inc., 6 U.S.P.Q.2d 1228, 1230-31 (Fla. Dist. Ct. App.) (Spanish restaurant diluted competitor's mark), rev. denied, 534 So.2d 399 (Fla. 1988); Gaeta Cromwell, Inc. v. Banyan Lakes Village, 523 So.2d 624 (Fla. Dist. Ct. App.) (office complex diluted competitor's mark), rev. denied, 531 So.2d 1353 (Fla. 1988).

206. See WAWA Inc. v. Haaf, 40 U.S.P.Q.2d 1629 (E.D. Pa. 1996) (HAHA for convenience store dilutes WAWA, also for convenience store); Gazette Newspapers, Inc. v. New Paper, Inc., 934 F.Supp. 688 (D. Md. 1996) (GAZZETTE for local news weekly diluted by GAZZETTE, also for local news weekly).

207. See, e.g., Filter Dynamics Int'l, Inc. v. Astron Battery, Inc., 311 N.E.2d 386, 398-99 (Ill. Ct. App. 1974). Federal courts are bound by state court interpretations of state substantive law. See Erie R.R. Co. v. Tompkins, 304 U.S. 64 (1937).

208. See, e.g., Compania Cervecera De Nicaragua v. Cervezas Victoria Y Tona Beers, Inc., 28 U.S.P.Q.2d 1870 (M.D. Fla. 1993) (beer manufacturer diluted competitor's mark); Chassis Master Corp. v. Borrego, 225 U.S.P.Q. 1240 (S.D. Fla. 1985) (auto repair shop diluted competitor's mark). 
cutting edge issues facing owners of famous brands. One can expect able lawyers, armed with the federal statute, to argue that a variety of innovative theories warrant recognition of the classic admonition against reaping where one has not sown.

For example, one area of potential development under both federal and state dilution statutes involves the current trend of retailers, private label manufacturers, and suppliers to adopt a simulation of a famous trade dress in order to trade on the commercial magnetism of that trade dress. They often do so for several reasons. First, they may wish to create an association with the famous brand and to suggest that the goods or services offered in connection with the look-alike trade dress are provided by the owner of the famous trade dress. Second, they may wish to suggest that their products are comparable to the product or service offered by the owner of the famous brand. The imitators' approach often is to argue that the private label manufacturer has prominently used a distinctly different word mark or "house mark" in connection with the look-alike trade dress in order to identify its products or services, thereby avoiding a likelihood of confusion. ${ }^{209}$

This approach leaves the commercial magnetism of the famous trade dress at risk unless its owner can establish likelihood of confusion by such arguments as the following: confusion still exists due to lack of care by consumers; ${ }^{210}$ consumer belief that the look-alike is a line extension of the famous brand; ${ }^{211}$ consumer belief that the private label product is manufactured by the owner of the famous trade dress; ${ }^{212}$ or the use of the look-alike trade dress falsely suggests that the private label product is comparable in quality to the name brand.

Surprisingly, although dilution may be the strongest basis for relief to the owner of the famous trade dress, dilution theories have not been a significant

209. Conopco, Inc. v. May Department Stores Co., 46 F.3d 1556, 1570-71 (Fed. Cir. 1994) (reversing finding that private label brand infringed VASELINE INTENSIVE CARE lotion) ("prominent placement of the Venture logo on the front of the Venture product" reduces likelihood of confusion), cert. denied, 115 S.Ct. 1724 (1995).

210. See, e.g., P.T.C. Brands, Inc. v. Conwood Co., 887 F. Supp. 963, 969 (W.D. Ky. 1995) (holding that trade dress associated with RED MAN tobacco infringed by private label look-alike, and stating that tobacco products are "impulse products" likely to be purchased without much care)

211. See, e.g., Nabisco Brands, Inc. v. Kaye, 760 F. Supp. 25, 27 (D. Conn. 1991) (A.1 likely to be confused with A.2., both for steak sauces) ("[T]he use of the numeral ' 2 ' as opposed to the numeral ' 1 ' rather than differentiate the product, in fact, increases the likelihood that consumers will believe that the defendant's product is simply a variation on the basic 'A.1.' sauce or a line extension which emanates from, or is authorized by or otherwise affiliated with the same source as the "A.1.' product.").

212. See, e.g., Tone Bros, Inc. v. Sysco Corp., 28 F.3d 1192, 1205 (Fed. Cir. 1994) (vacating summary judgment because genuine issues of material fact exist with regard to whether defendant infringed plaintiff's spice container design) (" $T$ T] he relevant consumer [may] not think that the company identified on the private label was the manufacturer of the spices and instead may attach significance as to the manufacturing source to the container itself."), cert. denied, 115 S.Ct. 1356 (1995); Benjamin Moore \& Co. v. Talon Paints Prods., 917 F. Supp. 331, 335-36 (D.N.J. 1996) (holding trade dress associated with manufacturer's AQUAGLO brand and private label brands infringed by look-alike). But see Conopco, Inc., 46 F.3d at 1563-64 (discrediting evidence of confusion based on consumers' "erroneous" assumption "that national brand manufacturers secretly market private label brands"). 
factor in private label or other look-alike trade dress cases. There is no reason, however, why a famous trade dress should not be viewed as any other trademark entitled to protection from dilution. ${ }^{213}$ If the courts embrace the federal dilution doctrine to the same degree as they have the unfair competition and infringement provisions of the Lanham Act, the federal and state dilution statutes should provide a valuable weapon to owners of famous trade dress who are seeking to prevent the depletion of brand equity by private label and other competitors.

As we begin the second half century under the Lanham Act, we can expect new, creative arguments and developments in these and other uncharted waters of trademark law.

213. On several occasions, courts have found dilution of a distinctive trade dress. See, e.g., Academy of Motion Picture Arts \& Sciences v. Creative House Promotions, 944 F.2d 1446, 1457 (9th Cir. 1991) (statuette similar to famous OSCAR award tarnishes its image as a "coveted symbol of excellence"); Coca-Cola Co. v. Alma-Leo U.S.A., Inc., 719 F. Supp. 725, 728 (N.D. Ill. 1989) (distinctive shape of Coke bottle trade dress diluted similar bottle for bubble gum powder); Soft Sheen Prods. v. Revlon, Inc., 675 F. Supp. 408, 416 (N.D. Ill. 1987) (plaintiff's bright yellow and red trade dress on product containers diluted by similar trade dress). 
